\title{
Antiangiogenic agents in the treatment of recurrent or newly diagnosed glioblastoma: Analysis of single-agent and combined modality approaches
}

\author{
Kathryn Beal ${ }^{1 *}$, Lauren E Abrey², Philip H Gutin ${ }^{3}$
}

\begin{abstract}
Surgical resection followed by radiotherapy and temozolomide in newly diagnosed glioblastoma can prolong survival, but it is not curative. For patients with disease progression after frontline therapy, there is no standard of care, although further surgery, chemotherapy, and radiotherapy may be used. Antiangiogenic therapies may be appropriate for treating glioblastomas because angiogenesis is critical to tumor growth. In a large, noncomparative phase II trial, bevacizumab was evaluated alone and with irinotecan in patients with recurrent glioblastoma; combination treatment was associated with an estimated 6-month progression-free survival (PFS) rate of 50.3\%, a median overall survival of 8.9 months, and a response rate of $37.8 \%$. Single-agent bevacizumab also exceeded the predetermined threshold of activity for salvage chemotherapy (6-month PFS rate, 15\%), achieving a 6-month PFS rate of $42.6 \%$ ( $p<0.0001)$. On the basis of these results and those from another phase II trial, the US Food and Drug Administration granted accelerated approval of single-agent bevacizumab for the treatment of glioblastoma that has progressed following prior therapy. Potential antiangiogenic agents-such as cilengitide and XL184-also show evidence of single-agent activity in recurrent glioblastoma. Moreover, the use of antiangiogenic agents with radiation at disease progression may improve the therapeutic ratio of single-modality approaches. Overall, these agents appear to be well tolerated, with adverse event profiles similar to those reported in studies of other solid tumors. Further research is needed to determine the role of antiangiogenic therapy in frontline treatment and to identify the optimal schedule and partnering agents for use in combination therapy.
\end{abstract}

\section{Introduction}

The incidence rates of primary malignant brain and central nervous system (CNS) cancers have increased over the last 3 decades [1], reaching an estimated rate of 6.8 new cases per 100,000 persons in the United States [2]. Glioblastoma is the most common primary malignant brain tumor and accounts for the majority of diagnoses. On the basis of data collected between 1995 and 2006, glioblastoma has been associated with a particularly poor prognosis, with survival rates at 1 and 5 years equaling $33.7 \%$ and $4.5 \%$, respectively [3]. The current standard of care for patients with newly diagnosed

\footnotetext{
* Correspondence: bealk@mskcc.org

'Department of Radiation Oncology, Memorial Sloan-Kettering Cancer

Center, 1275 York Avenue, New York, NY 10021, USA

Full list of author information is available at the end of the article
}

glioblastoma is surgical resection followed by fractionated external beam radiotherapy and systemic temozolomide [4], as supported by data from a randomized phase III trial, which demonstrated a significant improvement with the addition of temozolomide to radiotherapy in median overall survival (OS) from 12.1 months to 14.6 months [5]. Although this treatment can prolong survival, it is not curative. The vast majority of patients with glioblastoma experience recurrent disease, with a median time to recurrence of 7 months [6].

Currently, there is no standard treatment for patients with recurrent glioblastoma, although additional surgery, chemotherapy, and radiotherapy are used. An analysis of data from phase II clinical trials showed the limitations of conventional chemotherapy regimens, which were associated with a 6 -month progression-free survival

\section{C) Biomed Central}


(PFS) rate of $15 \%$ and a median OS of 25 weeks in patients with recurrent disease [7]. More recent trials of single-agent temozolomide or irinotecan, also known as CPT-11, have demonstrated only slight increases in 6-month PFS, with the highest rate being 26\% [8-10]. Recommended chemotherapeutic options for recurrent glioblastoma include temozolomide, nitrosourea, cyclophosphamide, platinum-based combination regimens, and procarbazine, lomustine, and vincristine combination therapy [4]. Moreover, in May 2009, the US Food and Drug Administration (FDA) granted accelerated approval of single-agent bevacizumab for the treatment of patients with glioblastoma that has progressed following prior therapy [11]. The National Comprehensive Cancer Network (NCCN) guidelines have subsequently been amended to include a recommendation for the use of bevacizumab, with or without chemotherapy (i.e., irinotecan, bischloroethylnitrosourea, or temozolomide), for progressive glioblastoma [4]. Enrollment in a clinical trial is considered standard practice at recurrence.

Bevacizumab is a humanized monoclonal antibody that targets vascular endothelial growth factor (VEGF), an important mediator of angiogenesis that is essential for the tumorigenesis of glioblastoma. Antiangiogenic therapies may arrest tumor growth by mediating the regression of existing tumor vasculature and preventing regrowth over time $[12,13]$. As a result, bevacizumab and other antiangiogenic agents, including cediranib (AZD2171), aflibercept (VEGF Trap), XL184 and cilengitide (EMD 121974), are being evaluated for use in recurrent and newly diagnosed glioblastoma (Figure 1). This article reviews the available data from clinical trials of antiangiogenic agents in glioblastoma, either as single agents or in combination with chemotherapy and/or radiotherapy.

\section{Rationale For Using Antiangiogenic Therapies In The Treatment Of Glioblastoma}

Glioblastomas are associated with a high degree of microvascular proliferation, and the extent of proliferation correlates with an increased risk of recurrence and poor survival [14]. VEGF-A (also known as "VEGF") is one of the most well-studied and potent vascular permeability factors, with an established role in pathologic angiogenesis [15]. Studies evaluating VEGF levels in plasma and tumor fluid from patients have shown that glioblastomas express relatively high levels of VEGF $[16,17]$, and mean intracavitary levels of VEGF are significantly increased in patients with recurrent glioblastoma relative to those with nonrecurrent disease [16]. Moreover, there is a direct correlation between VEGF overexpression and poor prognosis in this tumor histology [18].

Preclinical studies have provided evidence that the inhibition of the VEGF ligand can modulate tumor vasculature. In a study using neuroblastoma xenografts, Dickson and colleagues demonstrated that treatment with bevacizumab led to reductions in microvessel density and improvement in the function of intratumoral blood vessels (Figure 2), facilitating the penetration of subsequent chemotherapy [19]. In another glioblastoma model, bevacizumab suppressed both the proangiogenic effects of stem cell-like glioma cells (SCLGCs) in vitro and the growth of SCLGC-derived glioblastoma xenografts in vivo [20]. Data also suggest an association between other proangiogenic factors, such as the angiopoietins, neuropilin-1, and delta-like ligands, and the survival and/or proliferation of tumor cells [21-23]. Collectively, these results highlight the importance of VEGF and the related signal transduction pathways as therapeutic targets in glioblastoma and provide the rationale for evaluating antiangiogenic agents in clinical trials.

\section{Clinical Experience With Antiangiogenic Agents In Glioblastoma}

\section{Antiangiogenic agents with chemotherapy for recurrent} glioblastoma

In the initial investigation in patients with recurrent glioblastoma, bevacizumab was evaluated in combination with concomitant irinotecan [24]. This combination was supported by the activity of bevacizumab with irinotecan-containing regimens in patients with metastatic colorectal cancer [25], by the relative lack of single-agent activity of thalidomide in recurrent glioblastoma [26], and by preclinical evidence, suggesting that antiangiogenic agents enhance intratumoral chemotherapy delivery $[19,27]$. Additionally, antiangiogenic agents may supplement the effect of chemotherapy by inhibiting the activity of a population of SCLGCs that is not as well differentiated (i.e., chemotherapy-resistant) [20]. The existence of these cells may partially explain tumor resistance to radiotherapy and chemotherapy, and could contribute to the recurrence of glioblastoma.

\section{Use of bevacizumab with chemotherapy}

Data from prospective and retrospective studies indicate that regimens combining bevacizumab and chemotherapy produce superior outcomes relative to those with conventional chemotherapy in patients with recurrent glioblastoma [7]. In the first prospectively designed, phase II trial, patients with recurrent glioblastoma received bevacizumab plus irinotecan in one of two treatment cohorts: the first cohort $(n=23)$ received bevacizumab $10 \mathrm{mg} / \mathrm{kg}$ plus irinotecan $\mathrm{q} 2 \mathrm{w}$ in a 6-week cycle, and a second cohort $(\mathrm{n}=12)$ received bevacizumab $15 \mathrm{mg} / \mathrm{kg} \mathrm{q3} \mathrm{w}$ with irinotecan on days $1,8,22$, and 29 of a 6 -week cycle $[28,29]$. In both cohorts, irinotecan was administered at $340 \mathrm{mg} / \mathrm{m}^{2}$ to $350 \mathrm{mg} / \mathrm{m}^{2}$ in patients on enzyme-inducing antiepileptic drugs 


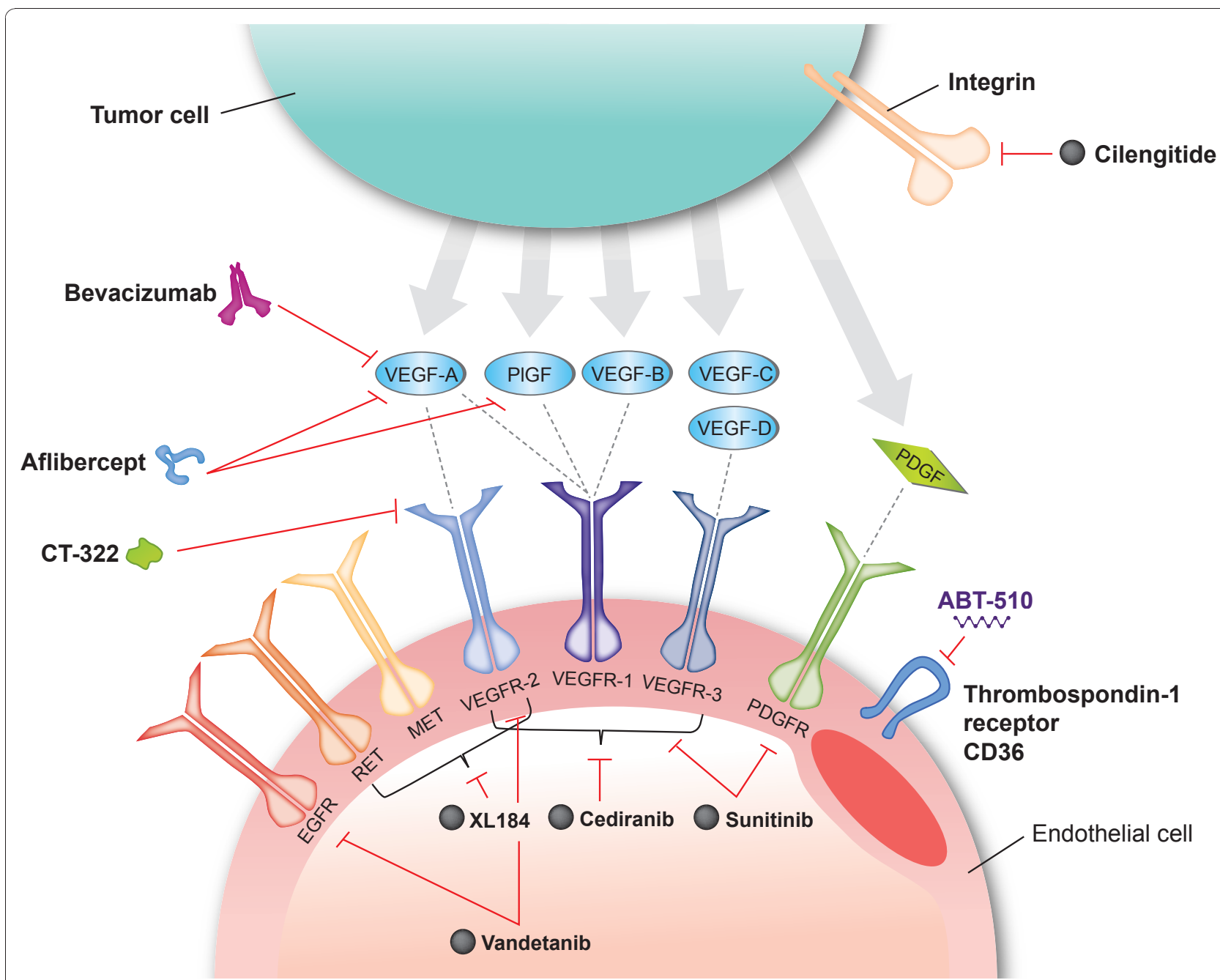

Figure 1 Molecular targets of antiangiogenic agents in glioblastoma. Cilengitide is a cyclic peptide that binds to and inhibits the activities of the alpha(v)beta(3) and alpha(v)beta(5) integrins. Bevacizumab is a humanized monoclonal immunoglobulin G1 antibody that binds to and inhibits VEGF-A. Aflibercept is a fusion protein that binds all isoforms of VEGF-A, as well as PIGF. Cediranib, sunitinib, vandetanib, XL184, and CT-322 are multireceptor tyrosine kinase inhibitors. ABT-510 is a nonapeptide that targets the thrombospondin-1 receptor CD36. Abbreviations: EGFR = epidermal growth factor receptor; PDGFR = platelet-derived growth factor receptor; PIGF = placental growth factor; VEGF-A = vascular endothelial growth factor A; VEGFR = vascular endothelial growth factor receptor.

(EIAEDs) and at $125 \mathrm{mg} / \mathrm{m}^{2}$ in those not receiving EIAEDs. The 6-month PFS rate among all 35 patients was $46 \%$, the 6 -month OS rate was $77 \%$, and the median OS was 42 weeks [29]. In addition, the overall response rate (ORR) was high (57\%). Recently, the 4-year survival rate in this trial was reported to be $11 \%$ [30] (Table 1). The toxicity of the combination of bevacizumab and irinotecan was considered to be significant but acceptable, considering the poor prognosis of the population [29]. Eleven (31\%) of the 35 patients discontinued treatment because of adverse events, which included thromboembolic complications $(n=4)$, grade 2 proteinuria $(n=2)$, and grade 2 fatigue $(n=4)$; one patient experienced a CNS hemorrhage.
More recently, Friedman and colleagues investigated the use of bevacizumab with or without irinotecan in a randomized noncomparative phase II trial of 167 patients with recurrent glioblastoma-the BRAIN study $[31,32]$. In this trial, patients were randomized to bevacizumab $10 \mathrm{mg} / \mathrm{kg}$ $\mathrm{q} 2 \mathrm{w}$ alone $(\mathrm{n}=85)$ or in combination with irinotecan $(\mathrm{n}=$ 82). For patients treated with bevacizumab and irinotecan, the estimated 6-month PFS rate was 50.3\%, the median OS was 8.9 months, and the ORR was $37.8 \%$ at the 6 month follow-up. At 27 months of follow-up, the 12-, 18-, $24-$, and 30 -month survival rates were $38 \%, 18 \%, 17 \%$, and $16 \%$, respectively. In the safety population for the combination arm $(n=79)$, the most common grade $\geq 3$ adverse events were convulsion (13.9\%), neutropenia (8.9\%), and 


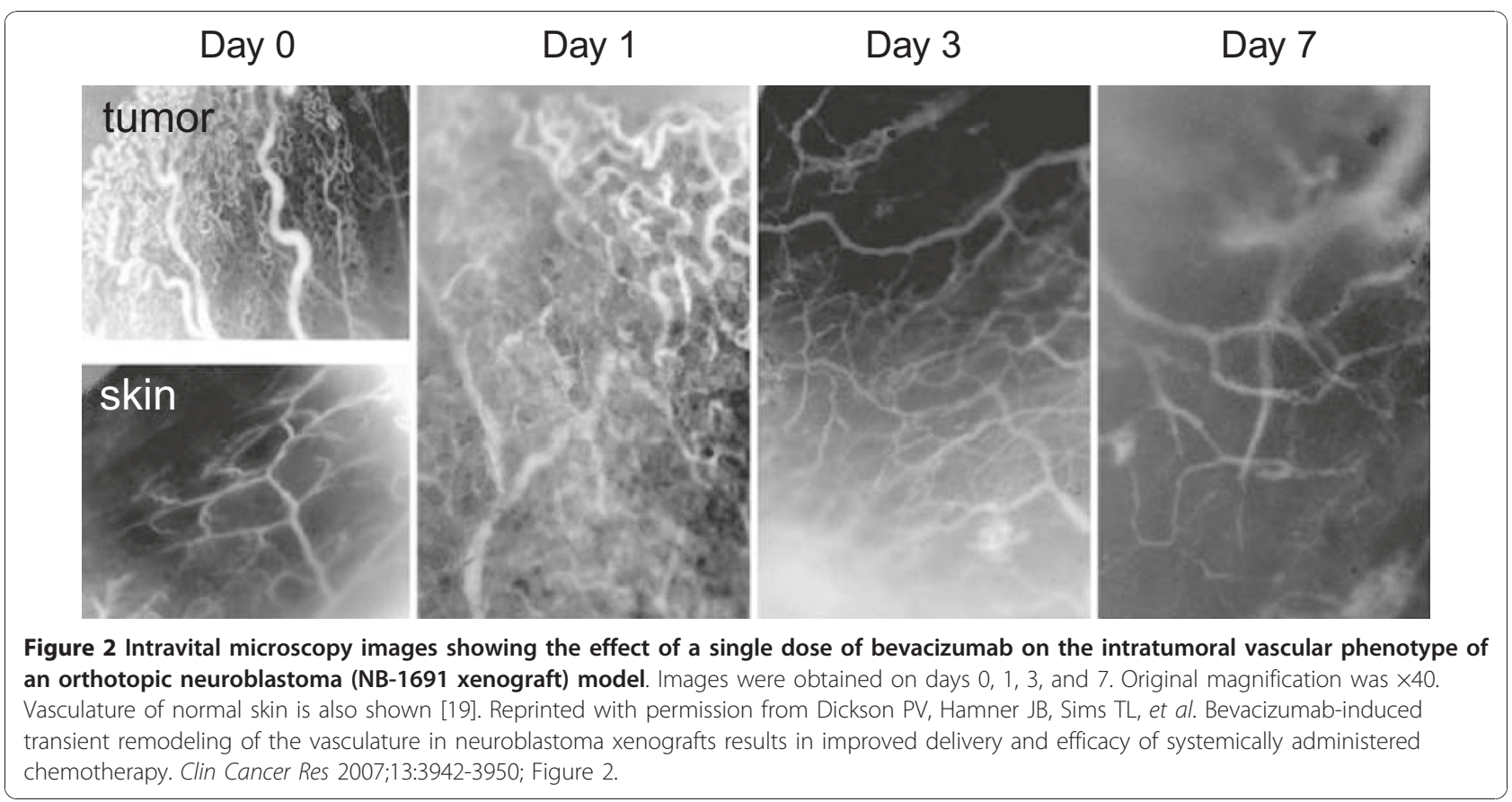

fatigue (8.9\%). Adverse events led to treatment discontinuation for 14 (17.7\%) patients. Adverse events associated with bevacizumab included grade $\geq 3$ arterial thromboembolism ( $2.5 \%)$, grade $\geq 3$ wound-healing complications (1.3\%), grade $\geq 3$ venous thromboembolism (10.1\%), grade 3 gastrointestinal perforation (2.5\%), serious reversible posterior leukoencephalopathy syndrome (1.3\%), and intracranial hemorrhage $(3.8 \%)$. In addition, there was one death associated with convulsion in patients treated with bevacizumab and irinotecan.

Data from additional phase II studies, retrospective analyses, and case series of consecutive patients have provided further support for the activity of bevacizumab with chemotherapy in patients with recurrent glioblastoma [33-39]. In these studies, 6-month PFS rates have ranged from $6.7 \%$ to $64 \%$ in patients with recurrent glioblastoma. In general, bevacizumab was shown to be well tolerated in both prospective and retrospective studies, and no unexpected treatment-related adverse events were reported (Table 2). Reported events were typical of those associated with bevacizumab in the treatment of other tumor types. For example, hypertension and proteinuria have been reported as the most frequently occurring treatment-related adverse events in studies of bevacizumab therapy in other solid tumors $[11,25,40]$. The incidence of thromboembolic complications in patients with recurrent glioblastoma receiving bevacizumab plus chemotherapy ranged from $11.4 \%$ to $12.7 \%$ in the two prospective studies $[28,29,32]$. The relation of bevacizumab to these events, however, is unclear because patients with malignant gliomas are already at an increased risk for symptomatic venous thromboembolism. In a retrospective study of 9489 cases of malignant glioma, the 2-year cumulative incidence of venous thromboembolism was relatively high at $7.5 \%(\mathrm{n}=715$ cases) [41]. Furthermore, a diagnosis of glioblastoma was identified as a specific risk factor for venous thromboembolism (hazard ratio $[\mathrm{HR}]=1.7 ; 95 \%$ confidence interval $[\mathrm{CI}], 1.4-2.1)$. Overall, the safety profile of bevacizumab with chemotherapy has been within acceptable limits, without any indications of additive toxicities.

\section{Other antiangiogenic therapies used with chemotherapy for recurrent glioblastoma}

Clinical trials have also evaluated the safety and efficacy of other antiangiogenics, specifically thalidomide and vatalanib, in combination with chemotherapy agents. In phase II trials of patients with recurrent glioblastoma, thalidomidecontaining regimens produced 6-month PFS rates between $23 \%$ and $27 \%$ and objective response rates between $6 \%$ and $24 \%$ [42-45]. Although the findings of two of these studies suggested that combination therapy was more active than either thalidomide or the chemotherapy partner alone, the benefit-to-risk ratio of thalidomide-containing therapy has not been clearly established, particularly when considering that certain combinations are complicated by significant adverse events (e.g., neutropenia and thromboembolism). A phase I/II trial of vatalanib plus temozolomide $(n=37)$ or lomustine $(\mathrm{n}=23)$ provided evidence of activity in patients with recurrent glioblastoma-patients receiving vatalanib and temozolomide had a median time to progression of 16.1 weeks and a partial response rate of $9 \%$ 
Table 1 Efficacy outcomes with antiangiogenic agents in recurrent glioblastoma

\begin{tabular}{|c|c|c|c|c|c|c|}
\hline \multirow[t]{2}{*}{ Reference, $\left(n^{\mathrm{a}}\right)$} & \multirow[t]{2}{*}{ Treatment regimen } & \multicolumn{3}{|c|}{$\begin{array}{l}\text { Response rate } \\
(\%)^{\text {b }}\end{array}$} & \multicolumn{2}{|c|}{ Progression-free survival } \\
\hline & & CR & PR & SD & Median & $\begin{array}{l}\text { At } 6 \text { months } \\
(\%)\end{array}$ \\
\hline \multicolumn{7}{|l|}{ Bevacizumab } \\
\hline Vredenburgh [28], $(n=23 \text { of } 32)^{d}$ & $\mathrm{BV}+$ irinotecan & 4 & 57 & 35 & 20 weeks & 30 \\
\hline Vredenburgh [29], $(N=35)$ & $\mathrm{BV}+$ irinotecan & \multicolumn{2}{|c|}{57} & N/A & 24 weeks & 46 \\
\hline Narayana [33], $(n=37 \text { of } 61)^{e}$ & BV + irinotecan or carboplatin & 13 & 60 & 21 & 5 months & N/A \\
\hline $\begin{array}{l}\text { Friedman [31], Cloughesy [32], }(\mathrm{N} \\
=167)\end{array}$ & $\begin{array}{l}\text { BV alone }(n=85) \\
\text { BV + irinotecan }(n=82)\end{array}$ & \multicolumn{2}{|c|}{$\begin{array}{l}28 \\
38\end{array}$} & $\begin{array}{l}\text { N/A } \\
\text { N/A }\end{array}$ & $\begin{array}{l}4.2 \text { months } \\
5.6 \text { months }\end{array}$ & $\begin{array}{l}43 \\
50\end{array}$ \\
\hline Reardon [38], $(n=27 \text { of } 59)^{d}$ & BV + etoposide & \multirow{2}{*}{\multicolumn{2}{|c|}{$\begin{array}{l}71 \text { (Levin } \\
\text { criteria); } 35 \\
\text { (MacDonald } \\
\text { criteria) }\end{array}$}} & 70 & 18 weeks & 44 \\
\hline Kreisl [49], $(\mathrm{N}=48)$ & $\mathrm{BV} \rightarrow \mathrm{BV}+$ irinotecan & & & N/A & 16 weeks & 29 \\
\hline Gutin [92], $(n=20 \text { of } 25)^{d}$ & BV + hypofractionated stereotactic irradiation & \multirow{2}{*}{\multicolumn{2}{|c|}{50}} & N/A & 7.3 months & 65 \\
\hline \multicolumn{5}{|l|}{ Aflibercept } & & \\
\hline De Groot [53], $(n=32 \text { of } 48)^{d}$ & Aflibercept alone & 0 & 30 & 52 & N/A & N/A \\
\hline \multicolumn{7}{|l|}{ Cediranib } \\
\hline Batchelor [112], ( $N=31)$ & Cediranib alone & \multicolumn{2}{|c|}{$\begin{array}{c}57 \\
\text { (volumetric } \\
\text { criteria); } 27 \\
\text { (MacDonald } \\
\text { criteria) }\end{array}$} & N/A & 117 days & 26 \\
\hline \multicolumn{7}{|l|}{ Cilengitide } \\
\hline Reardon [50] ( $N=81)$ & $\begin{array}{l}\text { Cilengitide alone }(2000 \mathrm{mg} / \mathrm{d}[\mathrm{n}=40] \text { or } 500 \mathrm{mg} / \mathrm{d} \\
[n=41])\end{array}$ & 0 & 9 & N/A & $\begin{array}{c}2000 \mathrm{mg} / \mathrm{d}, 8.1 \\
\text { weeks } \\
500 \mathrm{mg} / \mathrm{d}, 7.9 \text { weeks }^{\mathrm{c}}\end{array}$ & $\begin{array}{c}2000 \mathrm{mg} / \mathrm{d}, 15 \\
500 \mathrm{mg} / \mathrm{d}, 10\end{array}$ \\
\hline \multicolumn{7}{|l|}{ CT-322 } \\
\hline Schiff [113], $(n=51)$ & $\begin{array}{l}\text { CT-322 alone }(n=33) \\
\text { CT-322 + irinotecan }(n=18)\end{array}$ & $\begin{array}{c}1(3) \\
0\end{array}$ & $\begin{array}{c}1(3) \\
0\end{array}$ & $\begin{array}{l}\text { N/A } \\
\text { N/A }\end{array}$ & $\begin{array}{l}\text { N/A } \\
\text { N/A }\end{array}$ & $\begin{array}{l}23 \\
48\end{array}$ \\
\hline \multicolumn{7}{|l|}{ XL184 } \\
\hline Wen [54], $(n=105)$ & $\begin{array}{l}\text { XL184 } 175 \text { mg qd } \\
\text { XL } 184125 \text { mg qd }\end{array}$ & \multicolumn{2}{|c|}{$\begin{array}{c}\text { AAT-naive ( } \mathrm{n} \\
=34), 21 \\
\text { AAT- } \\
\text { pretreated } \\
(\mathrm{n}=12), 8 \\
\text { AAT-naive ( } \mathrm{n} \\
=37), 30 \\
\text { AAT- } \\
\text { pretreated } \\
(\mathrm{n}=22), 0\end{array}$} & N/A & $\begin{array}{l}\text { AAT-naive, } 16 \text { weeks } \\
\text { AAT-naive, } 16 \text { weeks } \\
\text { AAT-pretreated, } 7.9 \\
\text { weeks }\end{array}$ & $\begin{array}{l}\text { AAT-naive, } 10 \\
\text { AAT-naive, } 25 \\
\text { AAT- } \\
\text { pretreated, } 0\end{array}$ \\
\hline
\end{tabular}

Abbreviations: $\mathrm{AAT}=$ antiangiogenic therapy; $\mathrm{BV}=$ bevacizumab; $\mathrm{CR}=$ complete response; $\mathrm{N} / \mathrm{A}=$ not available; $\mathrm{PR}=$ partial response; $\mathrm{RT}=$ radiotherapy; $\mathrm{SD}=$ stable disease.

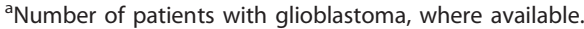

${ }^{\mathrm{b}}$ In evaluable patients.

'Time to progression.

${ }^{\mathrm{d} E f f i c a c y}$ outcomes are reported for patients with glioblastoma only.

eEfficacy outcomes are reported for all patients.

across all dose groups [46]. However, vatalanib has since been discontinued from further investigation in patients with glioblastoma.

\section{Single-agent activity of antiangiogenic therapies in recurrent glioblastoma}

As data from trials of antiangiogenic agents and chemotherapy in the recurrent setting began to emerge, questions arose about the relative contribution of concomitant cytotoxic therapy in these regimens. Single-agent antiangiogenic strategies were effective in other solid tumors, including renal cell carcinoma and ovarian cancer $[40,47,48]$. Thus, clinical trials were initiated to investigate whether single-agent approaches were appropriate in patients with recurrent glioblastoma, anticipating that they might provide antitumor control while minimizing toxicity. 
Table 2 Safety profile of antiangiogenic agents for recurrent glioblastoma

\begin{tabular}{|c|c|c|c|c|c|c|}
\hline Reference, $\left(n^{\mathrm{a}}\right)$ & $\begin{array}{l}\text { Treatment } \\
\text { regimen }\end{array}$ & $\begin{array}{c}\text { Patients } \\
\text { discontinuing } \\
\text { because of an } \\
\text { adverse event, } \\
\mathbf{n}(\%)\end{array}$ & $\begin{array}{c}\text { Select grade } 3 \text { or } 4 \\
\text { adverse events, } \\
n(\%)^{b}\end{array}$ & $\begin{array}{l}\text { Intracranial } \\
\text { hemorrhage } \\
\text { (any grade), } \\
\text { n (\%) }\end{array}$ & $\begin{array}{l}\text { Thromboembolic } \\
\text { events } \\
\text { (any grade), } \\
\text { n (\%) }\end{array}$ & $\begin{array}{l}\text { Treatment- } \\
\text { related } \\
\text { deaths, } \\
\mathrm{n}(\%)\end{array}$ \\
\hline \multicolumn{7}{|c|}{ Bevacizumab-containing regimens } \\
\hline $\begin{array}{l}\text { Vredenburgh [28], } \\
(n=23 \text { of } 32)^{c}\end{array}$ & BV + irinotecan & $9(28.1)$ & N/A & 0 & $4(12.5)$ & $2(6.3)$ \\
\hline $\begin{array}{l}\text { Vredenburgh [29], } \\
(\mathrm{N}=35)\end{array}$ & BV + irinotecan & $11(31.4)$ & N/A & $1(2.9)$ & $4(11.4)$ & N/A \\
\hline $\begin{array}{l}\text { Narayana [33], } \\
(n=37 \text { of } 61)^{c}\end{array}$ & $\begin{array}{l}\text { BV + irinotecan or } \\
\text { carboplatin }\end{array}$ & $16(26.2)$ & Bone marrow toxicity, 6 (9.8) & $6(9.8)$ & $6(9.8)$ & 0 \\
\hline $\begin{array}{l}\text { Friedman [31], } \\
\text { Cloughesy [32], } \\
(\mathrm{N}=167)\end{array}$ & $\begin{array}{l}\text { BV alone }(\mathrm{n}=84) \\
\text { BV }+ \text { irinotecan }(\mathrm{n} \\
=79)\end{array}$ & $\begin{array}{c}4(4.8) \\
14(17.7)\end{array}$ & $\begin{array}{c}\text { All, } 43 \text { (51.2) } \\
\text { Hypertension, } 9 \text { (10.7) } \\
\text { Wound-healing complications, } 2 \text { (2.4) } \\
\text { Proteinuria, } 1 \text { (1.2) } \\
\text { All, } 56 \text { (70.9) } \\
\text { Hypertension, } 3 \text { (3.8) } \\
\text { Wound-healing complications, } 1 \text { (1.3) } \\
\text { Proteinuria, } 3 \text { (3.8) } \\
\text { Gl perforation, } 2 \text { (2.5) }\end{array}$ & $\begin{array}{l}3(3.6) \\
3(3.8)\end{array}$ & $\begin{array}{l}\text { ATE, } 4 \text { (4.8) } \\
\text { VTE, } 3 \text { (3.6) } \\
\text { ATE, } 3 \text { (3.8) } \\
\text { VTE, } 9(11.4)\end{array}$ & $\begin{array}{l}2(2.4) \\
1(1.3)\end{array}$ \\
\hline $\begin{array}{l}\text { Reardon [38], } \\
(\mathrm{n}=27 \text { of } 59)^{c}\end{array}$ & BV + etoposide & $7(11.9)$ & $\begin{array}{c}\text { Neutropenia, } 14 \text { (23.7) } \\
\text { Infection, } 5 \text { (8.5) } \\
\text { Hypertension, } 2 \text { (3.4) }\end{array}$ & $\begin{array}{c}\text { CNS } \\
\text { hemorrhage, } 2 \\
(3.4)\end{array}$ & $7(11.9)$ & $1(1.7)$ \\
\hline $\begin{array}{l}\text { Kreisl [49], } \\
(\mathrm{N}=48)\end{array}$ & $\begin{array}{l}\mathrm{BV} \rightarrow \mathrm{BV}+ \\
\text { irinotecan }\end{array}$ & $6(12.5)$ & $\begin{array}{l}\text { Hypertension, } 2 \text { (4.2) } \\
\text { Hypophosphatemia, } 2 \text { (4.2) } \\
\text { Bowel perforation, } 1 \text { (2.1) }\end{array}$ & 0 & $6(12.5)$ & N/A \\
\hline $\begin{array}{l}\text { Gutin [92], } \\
(\mathrm{n}=20 \text { of } 25)^{\mathrm{c}}\end{array}$ & $\begin{array}{l}\text { BV }+ \\
\text { hypofractionated } \\
\text { stereotactic } \\
\text { irradiation }\end{array}$ & $3(12)$ & $\begin{array}{c}\text { Lymphopenia, } 9 \text { (36) } \\
\text { Hyponatremia, } 6 \text { (24) } \\
\text { Bowel perforation, } 1 \text { (4) } \\
\text { Wound-healing complication, } 1 \text { (4\%) } \\
\text { Gl bleeding, } 1 \text { (4\%) }\end{array}$ & $1(4)$ & N/A & N/A \\
\hline \multicolumn{7}{|l|}{ Aflibercept } \\
\hline $\begin{array}{l}\text { De Groot [53], } \\
(\mathrm{n}=32 \text { of } 48)^{c}\end{array}$ & Aflibercept alone & $12(25)$ & $\begin{array}{l}\text { CNS ischemia, } 1 \text { (2.1) } \\
\text { Systemic hemorrhage, } 1 \text { (2.1) }\end{array}$ & N/A & N/A & N/A \\
\hline \multicolumn{7}{|l|}{ Cediranib } \\
\hline $\begin{array}{l}\text { Batchelor [112], } \\
(\mathrm{N}=31)\end{array}$ & Cediranib alone & $2(6.5)$ & $\begin{array}{c}\text { Fatigue, } 6 \text { (19.4) } \\
\text { ALT, } 5 \text { (16.1) } \\
\text { Hypertension, } 4 \text { (12.9) }\end{array}$ & N/A & $1(3.2)$ & 0 \\
\hline \multicolumn{7}{|l|}{ Cilengitide } \\
\hline $\begin{array}{l}\text { Reardon }[50] \text {, Fink } \\
{[51],} \\
(N=81)\end{array}$ & $\begin{array}{l}\text { Cilengitide alone } \\
(2000 \mathrm{mg} / \mathrm{d}[\mathrm{n}= \\
40] \text { or } 500 \mathrm{mg} / \mathrm{d} \\
[\mathrm{n}=41])\end{array}$ & N/A & $\begin{array}{l}\text { Convulsion, } 2 \text { (2.5) } \\
\text { Lymphopenia, } 7 \text { (8.6) } \\
\text { Neutropenia, } 1 \text { (1.2) }\end{array}$ & $1(1.2)$ & N/A & $5(6.2)$ \\
\hline \multicolumn{7}{|l|}{ CT-322 } \\
\hline $\begin{array}{l}\text { Schiff [113], } \\
(n=51)\end{array}$ & $\begin{array}{l}\text { CT-322 } \pm \\
\text { irinotecan }\end{array}$ & $13(25.5)$ & $\begin{array}{l}\text { Neutropenia, } 4 \text { (7.8) } \\
\text { Hypertension, } 3 \text { (5.9) }\end{array}$ & $\begin{array}{c}\text { CNS } \\
\text { hemorrhage, } 1 \\
(2.0)\end{array}$ & N/A & $1(2.0)$ \\
\hline \multicolumn{7}{|l|}{ XL184 } \\
\hline $\begin{array}{l}\text { Wen [54], } \\
(n=153)\end{array}$ & $\begin{array}{l}X L 184(175 \mathrm{mg} \\
\mathrm{qd}[\mathrm{n}=46] \text { or } \\
125 \mathrm{mg} \text { qd }[\mathrm{n}= \\
107])\end{array}$ & $18(11.8)$ & $\begin{array}{c}\text { Fatigue, } 31 \text { (20.3) } \\
\text { Hypertension, } 8 \text { (5.2) } \\
\text { Gl perforation, } 3(2.0) \\
\text { Wound-healing complications, } 2 \text { (1.3) }\end{array}$ & $\begin{array}{l}3(2.0 ; \text { grade } \\
3 / 4)\end{array}$ & $17(11.1)$ & N/A \\
\hline
\end{tabular}

Abbreviations: ALT = alanine transaminase; $\mathrm{ATE}=$ arterial thromboembolic event; $\mathrm{BV}=$ bevacizumab; $\mathrm{CNS}=$ central nervous system; GI = gastrointestinal; $\mathrm{N} / \mathrm{A}=$ not available; $\mathrm{VTE}=$ venous thromboembolic event.

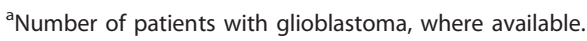

${ }^{b}$ Intracranial hemorrhage and thromboembolic events are reported separately.

'Safety outcomes are reported for all patients. 


\section{Single-agent bevacizumab}

The approval of single-agent bevacizumab treatment for patients with recurrent glioblastoma was based on an improvement in objective response rates in two phase II studies [31,49]. In a study by Kreisl and colleagues, 48 patients with heavily pretreated glioblastoma (median of two prior chemotherapy regimens) received bevacizumab $10 \mathrm{mg} / \mathrm{kg}$ q2w until disease progression [49]. At progression, patients received bevacizumab plus irinotecan. During the monotherapy phase of the study, the median PFS was 16 weeks (95\% CI, 12-26 weeks), the 6-month PFS rate was $29 \%$ (95\% CI, $18 \%-48 \%$ ), and the ORR was $35 \%$ (one complete response). When response assessment criteria were based on both World Health Organization (WHO) radiographic criteria and on stable or decreasing corticosteroid use, the objective response rate was $19.6 \%$ (95\% CI, 10.9\%-31.3\%) [11]. The median OS was 31 weeks (95\% CI, 21-54 weeks), and the 6-month OS was $57 \%$ (95\% CI, 44\%-75\%). Single-agent bevacizumab was well tolerated; the most frequently observed treatment-related adverse events were grade 3 or 4 thromboembolic events (12.5\%), grade 2 or 3 hypertension (12.5\%), grade 2 or 3 hypophosphatemia (6\%), and grade 2 or 3 thrombocytopenia (6\%). Of the six patients $(12.5 \%)$ who experienced a thromboembolic event, three had pulmonary emboli and one had a cerebral vascular event. Thromboembolic events in five patients and one instance of bowel perforation in another led to the removal of six patients (12.5\%) from the study. No instances of intracranial hemorrhage were reported.

The safety and efficacy of single-agent bevacizumab was further substantiated by a large, randomized, noncomparative phase II study (BRAIN) in which patients with glioblastoma in first or second relapse were randomized to bevacizumab alone or in combination with irinotecan $[31,32]$. Outcomes for patients treated with both bevacizumab and irinotecan in the BRAIN study have been described earlier. Patients who received bevacizumab monotherapy $(\mathrm{n}=85)$ had a 6 -month PFS rate of $42.6 \%$ (95\% CI, $29.6 \%-55.5 \%$ ), an ORR of $28.2 \%$ (one complete response), and a median OS of 9.3 months. Responses, categorized both by WHO radiographic criteria and by stable or decreasing corticosteroid use, were seen in $25.9 \%$ (95\% CI, $17.0 \%-36.1 \%$ ) of patients [11]. As in the combination arm, the 6-month PFS rate in the monotherapy arm surpassed the $15 \%$ rate assumed for salvage chemotherapy and single-agent irinotecan ( $\mathrm{p}<0.0001)$. The 12-, 18-, 24-, and 30-month OS rates were $38 \%, 24 \%, 16 \%$, and $11 \%$, respectively. No unexpected adverse events were reported, and there was a low incidence of intracranial hemorrhage. Forty-three (51.2\%) patients eligible for the safety analysis $(n=84)$ had grade $\geq 3$ adverse events, including hypertension
(10.7\%), venous thromboembolism (3.6\%), wound-healing complications $(2.4 \%)$, and arterial thromboembolism (3.6\%). Three (3.4\%) patients who received single-agent bevacizumab experienced intracranial hemorrhage; all of these events were grade $\leq 2$. Two patients died as a result of an adverse event (neutropenia infection and pulmonary embolism, respectively), and four patients (4.8\%) discontinued bevacizumab treatment because of adverse events.

Although the randomized design of the trial was intended only to prevent bias in treatment assignment and not to compare outcomes in the two treatment groups, it is notable that bevacizumab monotherapy was associated with a lower rate of grade $\geq 3$ adverse events (51.2\% vs $70.9 \%)$ than the combination of bevacizumab and irinotecan [32]. Furthermore, in the two studies evaluating bevacizumab monotherapy [31,49], the rate of treatment discontinuation owing to adverse events was relatively low ( $4.8 \%$ and $12.5 \%$, respectively) compared with discontinuation rates in the bevacizumab-plus-irinotecan arms of the Friedman and Vredenburgh studies (17.7\% and $31 \%$, respectively) $[29,31]$. This suggests that the rate of certain adverse events, such as infection, may be reduced or even eliminated by the omission of chemotherapy.

\section{Single-agent data with other antiangiogenic agents}

A number of other antiangiogenic therapies have been studied or are being studied as single-agent therapy in patients with recurrent glioblastoma, including cilengitide, aflibercept, XL184, cediranib, sunitinib, and CT322 (see Tables 1 and 2). Long-term follow-up results with the integrin inhibitor cilengitide have recently been reported from a phase II trial in 81 patients with recurrent glioblastoma, in which cilengitide $500 \mathrm{mg}(\mathrm{n}=41)$ or $2000 \mathrm{mg}(\mathrm{n}=40)$ was given twice weekly $[50,51]$. Median OS was 9.9 months in the 2000-mg arm compared with 6.5 months in the 500-mg arm. OS rates were consistently greater with the 2000-mg dose of cilengitide $(37 \%, 23 \%, 15 \%$, and $10 \%$ at $12,24,36$, and 48 months, respectively) compared with the 500-mg dose $(22 \%, 12 \%, 5 \%$, and $2 \%$, at $12,24,36$, and 48 months, respectively) $(\mathrm{HR}=0.635)$. Cilengitide was well tolerated, with no significant reproducible toxicities in the dose groups. For the 15 patients who received cilengitide for more than 6 months, treatment-related adverse events tended to occur within 6 months of receiving the first dose of cilengitide; the most common treatment-related adverse event was fatigue $(\mathrm{n}=3)$, and the most common grade 3 or 4 serious adverse event was convulsion $(n=2)$. Only two patients reported serious adverse events from 6 months up to 4.5 years from the first cilengitide dose (headache and memory impairment). The investigators concluded that cilengitide monotherapy was well tolerated and feasible for $>4$ 
years of therapy, with long-term survival rates being consistently greater with the 2000-mg dose.

Aflibercept is a recombinantly produced fusion protein that binds both VEGF and placental growth factor and has been shown to suppress the growth of glioblastoma xenografts in murine models [52]. In NABTC 0601, an ongoing phase II study, patients with temozolomideresistant glioblastoma or anaplastic glioma at first relapse receive aflibercept $4 \mathrm{mg} / \mathrm{kg}$ q2w [53]. Preliminary efficacy data in 27 patients with glioblastoma revealed an ORR of $30 \%$. Aflibercept showed moderate tolerability-the rate of treatment discontinuation among all 48 enrolled patients was $25 \%$. Eighteen treatmentrelated, grade 3 adverse events were reported. Mature data will provide a better indication of the activity of single-agent aflibercept in the recurrent setting.

Recently, interim results from a phase II study of XL184, an oral inhibitor of multiple receptor tyrosine kinases that includes VEGF receptor 2, in previously treated progressive glioblastoma have been reported [54]. In the cohort treated with XL184 $175 \mathrm{mg}$ ( $\mathrm{n}=$ $46)$, the ORRs were $8 \%(1 / 12)$ and $21 \%(7 / 34)$ in patients with and without previous exposure to antiangiogenic treatment, respectively. While none of the 22 patients previously treated with antiangiogenic therapy responded to XL184 $125 \mathrm{mg}$, the ORR in patients with antiangiogenic-naive disease was 30\% $(11 / 37)$ with the $125-\mathrm{mg}$ dose. The median PFS in both antiangiogenic-naive cohorts was 16 weeks. In total, $61 \%(46 / 76)$ of patients on corticosteroids at baseline had a reduction in corticosteroid dose of at least $50 \%$. Common grade 3 or 4 adverse events among all 153 evaluable patients included fatigue $(20 \%)$, transaminase elevation (12\%), and thromboembolic events $(10 \%)$. The investigators concluded that XL184 demonstrates encouraging clinical activity in patients with progressive glioblastoma and that the 125 -mg dose of XL184 demonstrates improved tolerability compared with the 175-mg dose.

Continued use of antiangiogenic agents after progression In the event of progression following treatment with an antiangiogenic agent, patients with glioblastoma have very few therapeutic options. For example, in a prospective study by Kreisl and colleagues, a cohort of 19 patients was subsequently treated with bevacizumab plus irinotecan after progression on bevacizumab monotherapy [49]. None of these patients responded to therapy, and the median PFS was 30 days. In another prospective phase II study of patients with recurrent malignant gliomas treated with daily temozolomide, it was found that patients with prior exposure to bevacizumab fared worse than patients without bevacizumab exposure (6-month PFS rate of $14 \%$ vs $36 \%, p=0.12$; median OS of 4 vs 18 months, $\mathrm{p}=0.005$ ) [55]. Retrospective reviews of patients with glioblastoma treated either with a bevacizumab-containing regimen or bevacizumab alone have also reported that these patients have limited response to a second treatment, regardless of whether it contains bevacizumab [36,56-59]. One hypothesis for the lack of response after antiangiogenic treatment is that an alteration of the tumor phenotype results in a highly infiltrative compartment that is angiogenic-independent. Further studies are warranted to identify new therapeutic targets and novel agents that could treat patients who have relapsed following antiangiogenic therapy.

One of the concerns with the administration of antiangiogenic agents is the apparent potential for infiltrative or invasive tumor growth upon disease progression [33,35,36,60-62]. Recent reports, however, indicate that antiangiogenic treatments may not significantly alter patterns of relapse in glioblastoma. For example, in a study of distant spread in 44 matched pairs of patients with recurrent glioblastoma treated with or without bevacizumab-containing regimens, distant recurrences were later observed in $22 \%(10 / 44)$ of bevacizumab-treated patients compared with $18 \%(8 / 44)$ of non-bevacizumab-treated patients on $\mathrm{T}_{1}$-weighted magnetic resonance imaging (MRI) scans, and in 25\% (11/44) of bevacizumab-treated patients compared with $18 \%(8 / 44)$ of non-bevacizumab-treated patients on fluid attenuation inversion recovery (FLAIR) MRI sequences ( $p$ > 0.05). This proportion of distant recurrences was in line with previous reports, without significant differences between bevacizumab and non-bevacizumab-containing treatments [63]. Moreover, a subanalysis of the BRAIN study, in which patient MRI scans were compared at baseline (prior to bevacizumab treatment) and at the time of progression, showed that the majority of patients (55/67 in the bevacizumab-alone group) had no shift in the pattern of progression. A shift from local to diffuse disease was seen in $16 \%(11 / 67)$ of patients in the bevacizumab-alone group [64]. Other investigators have likewise concluded on the basis of retrospective analyses of radiographic patterns of relapse that the majority of disease patterns with glioblastoma are local at diagnosis and remain so after recurrence and treatment with bevacizumab, and that the rate of nonlocal disease (diffuse, distant, or multifocal) does not appear to increase with the use of antiangiogenic agents [65-67]. Reports have also differed regarding the impact of the pattern of radiographic recurrence on survival outcomes $[36,58,64,67]$. In cases in which an infiltrative phenotype is observed at diagnosis, it is possible that antiangiogenic therapy in combination with another agent that targets tumor invasion, such as dasatinib [68], may be an effective therapeutic strategy. 


\section{Antiangiogenic agents in combination with radiation} Increased understanding of molecular mechanisms in the tumorigenesis of glioblastomas has led to the evaluation of targeted agents as potential radiosensitizers $[69,70]$. Preclinical models have shown that VEGF is upregulated in response to radiation, and these elevations may contribute to the protection of tumor blood vessels from radiation-mediated cytotoxicity [70,71]. The administration of antiangiogenic agents with radiotherapy may counteract VEGF-mediated radioresistance, thereby sensitizing tumors and associated vasculature to the ionizing effects of radiation (Figure 3) [69,70,72]. As an underlying mechanism, the ability of antiangiogenic agents to lower tumor interstitial fluid pressure and improve vascular function and tumor oxygenation may promote enhanced responsiveness to radiotherapy $[73,74]$. Preclinical studies have also demonstrated that antiangiogenic agents uniquely target the radioresistant and highly tumorigenic cancer stem cell niche [20,75]. Finally, the success of initial clinical investigations of bevacizumab with chemoradiation in patients with solid tumors also supports the possible synergies of combined modality therapy $[76,77]$.

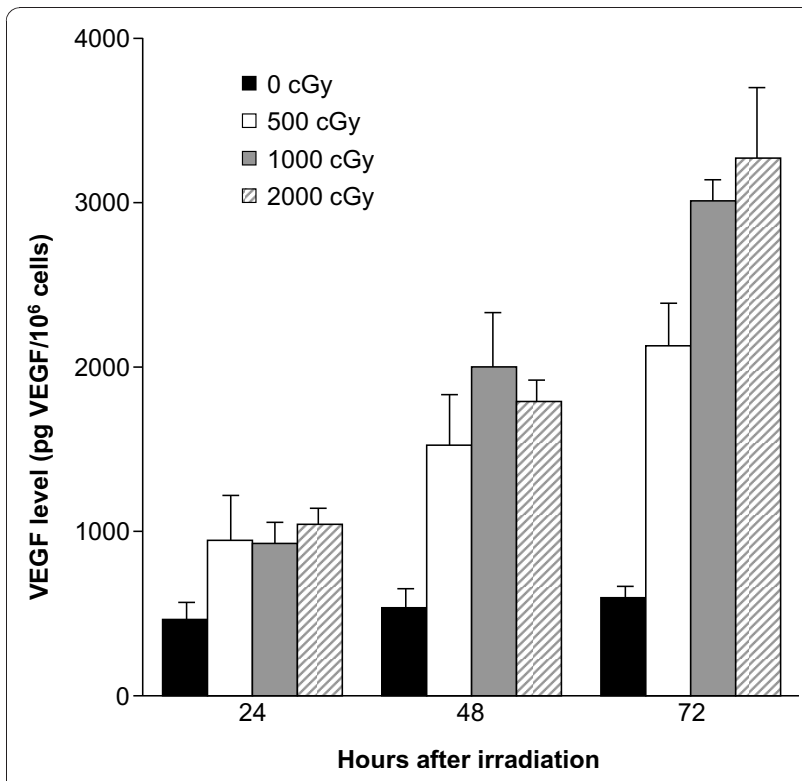

Figure 3 Dose-dependent effect of radiation on VEGF protein expression. VEGF protein levels in LLC-conditioned medium are shown after radiation exposure. LLCs were plated in six-well plates at $25 \%$ confluence, allowed to attach overnight, and then irradiated with 0, 5, 10, or 20 Gy. Conditioned medium was collected every 24 hours and VEGF levels were normalized to cell number. Data are presented as mean plus standard error [70]. Abbreviations: LLC = Lewis lung carcinoma; VEGF = vascular endothelial growth factor. Reprinted with permission from Gorski DH, Beckett MA, Jaskowiak NT, et al. Blockage of the vascular endothelial growth factor stress response increases the antitumor effects of ionizing radiation. Cancer Res 1999;59:3374-3378; Figure 1B.
Efficacy of antiangiogenic agents and chemoradiation The efficacy and safety of bevacizumab with chemotherapy and radiotherapy have been assessed in clinical studies for the treatment of both recurrent and newly diagnosed glioblastoma [78,79]. In the frontline setting, the use of bevacizumab plus radiotherapy and temozolomide has been described in two reports. In a phase II pilot study, 10 patients with glioblastoma underwent surgery followed by radiotherapy (30 fractions of 2 Gy per fraction) with bevacizumab $10 \mathrm{mg} / \mathrm{kg}$ q2w plus concomitant temozolomide $75 \mathrm{mg} / \mathrm{m}^{2}$ [78]. Temozolomide therapy was continued until disease progression or for a maximum of 24 cycles, while bevacizumab therapy continued every 2 weeks until progression. At the time of reporting, the median PFS was $>8.8$ months, but it was too early to establish the median OS. The most commonly occurring, possibly treatment-related adverse events were fatigue, myelotoxicity, wound-healing complications, and venous thromboembolic events. The only unexpected toxicity was the development of presumed radiation-induced optic neuropathy in one patient. The study investigators noted, however, that the observed toxicities were at an acceptable level to continue enrollment toward a target of 70 patients.

In a subsequent feasibility study in a consecutive series of patients, Narayana and colleagues reported outcomes from 15 patients with high-grade glioma, including 12 patients with glioblastoma, who underwent surgery followed by radiotherapy (59.4 Gy over 6.5 weeks) [79]. Bevacizumab $10 \mathrm{mg} / \mathrm{kg}$ was administered on days 14 and 28 along with concomitant temozolomide $75 \mathrm{mg} / \mathrm{m}^{2}$ daily during radiotherapy. After the completion of radiotherapy, treatment with bevacizumab and temozolomide continued for 12 cycles. At a median follow-up of 12 months (range, 5-21 months), the PFS rate was $59.3 \%$ and the OS rate was $86.7 \%$. Nonhematologic toxicities were reported in three patients $(20 \%)$, and grade 3 or 4 hematologic toxicities were reported in another three patients (20\%) [79]. No intracerebral hemorrhage or treatment-related deaths occurred during the study. Several ongoing clinical trials have also recently reported interim data on the use of bevacizumab with radiotherapy and either temozolomide or irinotecan in patients with previously untreated glioblastoma [80-86]. In two of the trials with longer follow-up, the addition of bevacizumab with or without irinotecan to standard radiotherapy and temozolomide was shown to provide significant benefit in PFS relative to historic controls $[80,82]$. In one trial having a minimum followup of 18 months, the regimen incorporating bevacizumab and irinotecan was associated with a median PFS that was approximately double that seen with standard therapy in patients with newly diagnosed glioblastoma (14 vs 6.9 months, respectively) [82]. In both trials, the 
incorporation of bevacizumab into standard frontline regimens was considered to be tolerable $[80,82]$. Large phase III studies evaluating bevacizumab-containing regimens in patients with newly diagnosed glioblastoma have recently begun enrolling patients, including a global-based study (AVAglio [NCT00943826]) [87] and a US-based study (RTOG-0825 [NCT00884741], which is sponsored by the Radiation Therapy Oncology Group).

Results from a phase I/II trial of cilengitide in combination with temozolomide and radiotherapy in patients with newly diagnosed glioblastoma have also demonstrated promising efficacy [88]. After tumor resection, 52 patients received standard radiotherapy $(2 \mathrm{~Gy} \times 30$ fractions) and temozolomide $75 \mathrm{mg} / \mathrm{m}^{2}$, with cilengitide $500 \mathrm{mg}$ twice weekly started 1 week before chemoradiation and given throughout the duration of chemotherapy or until progression. The 6-and 12-month PFS rates were $69 \%$ and $33 \%$, respectively; the median PFS was 8.0 months. The 12- and 24-month OS rates were $68 \%$ and $35 \%$, respectively, with a median OS of 16.1 months. The authors reported that PFS and OS in patients with $\mathrm{O}(6)$-methylguanine-DNA methyltransferase (MGMT) promoter methylation (13.4 and 23.3 months, respectively) were longer than those in patients without MGMT promoter methylation (3.4 and 13.1 months, respectively). Seven patients (14\%) discontinued treatment for adverse events that were possibly treatmentrelated. The regimen was found to be well tolerated, with no additional toxicities [88].

Early phase studies have evaluated additional antiangiogenic agents, such as vatalanib, vandetanib, and ABT510 , in combination with temozolomide and radiotherapy for the treatment of patients with newly diagnosed glioblastoma [89-91]. These trials provide further evidence for the feasibility of combining these treatment modalities in the frontline setting.

Recent studies have also reported on the feasibility of using bevacizumab with radiotherapy in patients with recurrent malignant gliomas [92,93]. One of these studies reported outcomes in 25 patients (20 patients with glioblastoma and five patients with anaplastic glioma) who received bevacizumab $10 \mathrm{mg} / \mathrm{kg}$ q2w until tumor progression, along with hypofractionated stereotactic radiotherapy (30 Gy total as $6 \mathrm{~Gy} \times 5$ fractions) after the first cycle of bevacizumab therapy [92]. In the glioblastoma cohort, the regimen was associated with a 6-month PFS rate of 65\% (95\% CI, 40\%-82\%) and a median PFS of 7.3 months (95\% CI, 4.4-8.9 months). The median OS was 12.5 months (95\% CI, 6.9-22.8 months), the 1 -year survival was $54 \%$, and the ORR was $50 \%$. The overall toxicity of the regimen was comparable to that in other clinical trials of bevacizumab in glioblastoma $[28,29,31,78]$. Three patients in the overall population experienced a grade 4 adverse event-bowel perforation, wound-healing complication, and gastrointestinal bleeding. Other nonhematologic and hematologic toxicities were transient. No significant adverse events appeared to be attributable to the interaction of bevacizumab with radiation, with the exception of a single instance of wound dehiscence; radiation necrosis was not observed in this previously irradiated population. Overall, the high 6-month PFS rate and improved therapeutic ratio of this combination suggest that it should be investigated in larger trials of patients with recurrent disease and supports ongoing trials of bevacizumab with radiochemotherapy in patients with newly diagnosed glioma.

\section{Other considerations with antiangiogenic therapies}

The role of antiangiogenic therapy also requires further evaluation of its potential use in glioblastoma-related conditions. One example is pseudoprogression, which may be visualized on brain scans in patients who have received chemoradiotherapy and temozolomide, resulting from increased cerebral edema. In clinical studies, both bevacizumab and cediranib have shown activity in reducing the need for steroid therapy to treat tumorassociated cerebral edema $[31,94]$. Therefore, these agents may be useful in cases in which pseudoprogression is suspected, as well as in patients with large, inoperable glioblastomas who are dependent on steroid therapy.

Antiangiogenic treatment has also been proposed for the management of radiation necrosis, a process in which endothelial cell dysfunction leads to tissue hypoxia and necrosis, with the concomitant release of vasoactive compounds [95]. In a small randomized double-blind study, Levin and colleagues reported outcomes in 14 patients who received either placebo or bevacizumab for radiographically-proven or biopsy-proven CNS necrosis. All of the bevacizumab-treated patients (5/5 randomized patients; $7 / 7$ crossover patients), but none of the placebotreated patients $(n=7)$, showed improvement in neurologic symptoms or signs and had a reduction in the volume of necrosis on $\mathrm{T}_{2}$-weighted FLAIR (average reduction of $59 \%$ in randomized patients) and $\mathrm{T}_{1}$-weighted gadolinium-contrast MRI (average reduction of $63 \%$ in randomized patients) [96]. Similar radiographic responses, along with improved or stable clinical outcomes, were also achieved with bevacizumab treatment in a retrospective analysis of eight patients with documented radiation necrosis [95], as well as a case series of six patients with biopsy-proven radiation necrosis [97].

In addition to its role in the treatment of glioblastoma, bevacizumab has also been evaluated in other highgrade gliomas. Results from phase II studies and retrospective reviews of bevacizumab for the treatment of anaplastic gliomas have been encouraging. In a phase II 
study of 33 patients with recurrent grade 3 malignant gliomas (anaplastic astrocytoma, anaplastic oligodendroglioma, and anaplastic oligoastrocytoma), Desjardins and colleagues found the use of bevacizumab and irinotecan to be active (6-month PFS $=55 \%$; 6-month OS $=79 \%$; ORR $=61 \%)$ and to have acceptable toxicity, with infrequent significant adverse events [98]. In a more recent study of 31 patients with recurrent anaplastic glioma, single-agent bevacizumab was associated with a median PFS of 3.7 months, a median OS of 12.4 months, reduced steroid requirements (a $40 \%$ reduction, on average, in steroid dose), and improved neurologic symptoms [99]. The activity and safety of single-agent bevacizumab have also been described in retrospective studies of patients with recurrent alkylator-refractory anaplastic oligodendroglioma and anaplastic astrocytoma $[100,101]$. The NCCN guidelines now include the use of bevacizumab with or without chemotherapy as a treatment option for recurrent anaplastic gliomas [4].

Another consideration is the impact of antiangiogenic agents on radiographic evaluations of treatment response in malignant gliomas. Some investigators argue that it is challenging to determine disease progression and tumor response to antiangiogenic therapy because of the effect of these agents on vascular permeability, which results in diminished contrast enhancement on computed tomography or MRI scans [102-104]. Because the current standard response criteria (MacDonald criteria) are based on contrast enhancement MRI, there is some debate as to whether these criteria are still adequate in the era of antiangiogenic agents. Proposals for new treatment response assessment criteria have been presented by various authors and also by the Response Assessment in NeuroOncology Working Group, and include taking into account $\mathrm{T}_{2}$ /FLAIR (non-contrast enhancing) imaging, favoring the use of Levin criteria, or changing the criterion of response by cross-sectional area of enhancement measurement (e.g., a $>25 \%$ decrease vs $\geq 50 \%$ decrease) $[35,99,105]$. Additional imaging techniques and analyses for the assessment or predictors of antiangiogenic treatment response that have been proposed for additional investigation include FLAIR MRI, dynamic contrastenhanced MRI, diffusion-weighted MRI, pretreatment apparent diffusion coefficient histogram analysis, and perfusion imaging or dynamic susceptibility contrast MRI [60,105-109]. The breadth of these recommendations further underscores the need for a standardized approach of response assessment.

\section{Summary and Conclusions}

Despite advances in treatment, glioblastoma has no cure, and patients with glioblastoma have poor long-term survival. Increased understanding of the tumorigenesis of this disease at the molecular level has led to the identification of VEGF and its related pathways as targets for therapy. As a result, a number of antiangiogenic therapies have been or are currently being evaluated in patients with glioblastoma, alone or in combination with chemotherapy and/or radiotherapy. The most wellestablished antiangiogenic therapy is bevacizumab; current experience encompasses clinical data from more than 1000 patients treated for glioblastoma. In May 2009 , single-agent bevacizumab was approved by the FDA for the treatment of patients with progressive glioblastoma following prior therapy on the basis of an improvement in objective response rate. The BRAIN study that supported this approval also showed a significant improvement in 6-month PFS rate with bevacizumab alone and in combination with irinotecan relative to historical controls [31]. At present, the NCCN guidelines include a recommendation for bevacizumab either with or without chemotherapy as a treatment option for recurrent glioblastoma [4]. The safety and efficacy of cilengitide with chemotherapy has not been reported in the recurrent setting, but single-agent data suggest that combinatorial trials are warranted.

Clinical studies have also demonstrated the feasibility of combining bevacizumab or cilengitide plus radiation with or without concomitant temozolomide for the treatment of patients with newly diagnosed or recurrent glioblastoma. Early data suggest the possibility of novel regimens that improve tumor response without overlapping toxicities, but these findings are preliminary. The incorporation of antiangiogenic agents in frontline therapy, therefore, cannot be recommended at present, except in the context of a clinical trial.

Although the safety and efficacy of combining antiangiogenic agents with chemotherapy has been documented in the recurrent setting, the ideal chemotherapy partner has yet to be identified by prospective, randomized trials. The difficulty of comparing data across trials prohibits any definitive conclusions, and the efficacy signals to date do not provide a clear indication as to which chemotherapy agents or treatment schedules are optimal. Moreover, the scheduling, timing, and dosing of antiangiogenic agents relative to chemotherapy also remains to be defined, and should be a focus of future studies. As the field progresses toward patient-specific approaches, gene expression studies and other correlative analyses are needed to assess the safety and efficacy of antiangiogenic therapies on the basis of the molecular pathophysiology of the disease. Data obtained from ongoing studies should enable clinicians to further optimize treatment for both newly diagnosed and recurrent glioblastoma (Additional file 1, Table S1). Additional information can be found at http://www.ro-journal.com. Alternate treatment strategies 
for patients with glioblastoma may include the use of an antiangiogenic agent with other targeted agents, such as erlotinib, dasatinib, or cetuximab [110,111]. More research is also needed to establish the most advantageous sequencing for individual components of combination regimens containing antiangiogenic therapies. Antiangiogenic agents are expected to play a significant role in the treatment of glioblastoma in the future, and it is hoped that the consideration of molecular profiling will further improve target selection.

\section{Additional material}

Additional file 1: Proposed and ongoing phase II and III trials of antiangiogenic agents in glioma. Table of proposed and ongoing phase II and phase III trials of select antiangiogenic agents for the treatment of recurrent and newly diagnosed glioma, with study details including NCT numbers, disease setting, primary endpoints, and leading study center.

\section{Acknowledgements}

Support for third-party writing assistance for this manuscript, furnished by Glen Miller and Denise Chun, was provided by Genentech, Inc.

\section{Author details}

${ }^{1}$ Department of Radiation Oncology, Memorial Sloan-Kettering Cancer Center, 1275 York Avenue, New York, NY 10021, USA. ${ }^{2}$ Department of Neurology, Memorial Sloan-Kettering Cancer Center, 1275 York Avenue, New York, NY 10021, USA. ${ }^{3}$ Department of Neurosurgery, Memorial SloanKettering Cancer Center, 1275 York Avenue, New York, NY 10021, USA.

\section{Authors' contributions}

$K B, L E A$, and PHG have contributed to the conception of the manuscript and the interpretations of the data contained within, and have been involved in critically revising the manuscript. All authors read and approved the final manuscript.

\section{Competing interests}

Dr. Beal acted as a consultant for Hoffman-La Roche at a single meeting. Her institution, Memorial Sloan-Kettering Cancer Center, has received research funding from Genentech, Inc., and Astra Zeneca. Dr. Abrey has been a consultant and on an advisory board for Genentech, Inc. Her institution, Memorial Sloan-Kettering Cancer Center, has received research funding from Genentech, Inc., and Astra Zeneca. Dr. Gutin has been on an advisory board for Genentech, Inc. His institution, Memorial Sloan-Kettering Cancer Center, has received research funding from Genentech and Astra Zeneca.

Received: 25 October 2010 Accepted: 7 January 2011

Published: 7 January 2011

\section{References}

1. Maher EA, McKee AC: Neoplasms of the central nervous system. In Atlas of diagnostic oncology.. 3 edition. Edited by: Skarin AT, Canellos GP. London: Elsevier Science; 2003:5-10

2. Jemal A, Siegel $R, X u$ J, Ward E: Cancer statistics, 2010. CA Cancer J Clin 2010, 60(5):277-300.

3. Central Brain Tumor Registry of the United States (CBTRUS): 2010 CBTRUS statistical report: primary brain and central nervous system tumors diagnosed in the United States in 2004-2006.[http://www.cbtrus.org/ reports/reports.html].

4. National Comprehensive Cancer Network clinical practice guidelines in oncology-central nervous system cancers. v.1.2010. [http://www.ncen.org/ professionals/physician_gls/PDF/cns.pdf].
5. Stupp R, Mason WP, van den Bent MJ, Weller M, Fisher B, Taphoorn MJ, Belanger K, Brandes AA, Marosi C, Bogdahn U, Curschmann J, Janzer RC, Ludwin SK, Gorlia T, Allgeier A, Lacombe D, Cairncross JG, Eisenhauer E, Mirimanoff RO, European Organisation for Research and Treatment of Cancer Brain Tumor and Radiotherapy Groups; National Cancer Institute of Canada Clinical Trials Group: Radiotherapy plus concomitant and adjuvant temozolomide for glioblastoma. N Engl J Med 2005, 352(10):987-996.

6. Wen PY, DeAngelis LM: Chemotherapy for low-grade gliomas: emerging consensus on its benefits. Neurology 2007, 68(21):1762-1763.

7. Wong ET, Hess KR, Gleason MJ, Jaeckle KA, Kyritsis AP, Prados MD, Levin VA, Yung WK: Outcomes and prognostic factors in recurrent glioma patients enrolled onto phase II clinical trials. J Clin Oncol 1999, 17(8):2572-2578.

8. Prados MD, Lamborn K, Yung WK, Jaeckle K, Robins HI, Mehta M, Fine HA, Wen PY, Cloughesy T, Chang S, Nicholas MK, Schiff D, Greenberg H, Junck L, Fink K, Hess K, Kuhn J, North American Brain Tumor Consortium: A phase 2 trial of irinotecan (CPT-11) in patients with recurrent malignant glioma: a North American Brain Tumor Consortium study. Neuro Oncol 2006, 8(2):189-193.

9. Cloughesy TF, Filka E, Kuhn J, Nelson G, Kabbinavar F, Friedman H, Miller LL, Elfring GL: Two studies evaluating irinotecan treatment for recurrent malignant glioma using an every-3-week regimen. Cancer 2003, 97(9 suppl):2381-2386.

10. Yung WK, Albright RE, Olson J, Fredericks R, Fink K, Prados MD, Brada M, Spence A, Hohl RJ, Shapiro W, Glantz M, Greenberg H, Selker RG, Vick NA, Rampling R, Friedman H, Phillips P, Bruner J, Yue N, Osoba D, Zaknoen S, Levin VA: A phase II study of temozolomide vs. procarbazine in patients with glioblastoma multiforme at first relapse. $\mathrm{Br} J$ Cancer 2000, 83(5):588-593.

11. Avastin ${ }^{\circledR}$ [package insert]. South San Francisco, CA: Genentech, Inc; 2009.

12. Inai T, Mancuso M, Hashizume H, Baffert F, Haskell A, Baluk P, Hu-Lowe DD, Shalinsky DR, Thurston G, Yancopoulos GD, McDonald DM: Inhibition of vascular endothelial growth factor (VEGF) signaling in cancer causes loss of endothelial fenestrations, regression of tumor vessels, and appearance of basement membrane ghosts. Am J Pathol 2004, 165(1):35-52.

13. Huang J, Frischer JS, Serur A, Kadenhe A, Yokoi A, McCrudden KW, New T, OToole K, Zabski S, Rudge JS, Holash J, Yancopoulos GD, Yamashiro DJ, Kandel JJ: Regression of established tumors and metastases by potent vascular endothelial growth factor blockade. Proc Natl Acad Sci USA 2003, 100(13):7785-7790.

14. Chi A, Norden AD, Wen PY: Inhibition of angiogenesis and invasion in malignant gliomas. Expert Rev Anticancer Ther 2007, 7(11):1537-1560.

15. Norden AD, Drappatz J, Wen PY: Novel anti-angiogenic therapies for malignant gliomas. Lancet Neurol 2008, 7(12):1152-1160.

16. Salmaggi A, Eoli $M$, Frigerio $S$, Silvani A, Gelati $M$, Corsini E, Broggi $G$, Boiardi A: Intracavitary VEGF, bFGF, IL-8, IL-12 levels in primary and recurrent malignant glioma. J Neurooncol 2003, 62(3):297-303.

17. Takano S, Yoshii Y, Kondo S, Suzuki H, Maruno T, Shirai S, Nose T: Concentration of vascular endothelial growth factor in the serum and tumor tissue of brain tumor patients. Cancer Res 1996, 56(9):2185-2190.

18. Nam DH, Park K, Suh YL, Kim JH: Expression of VEGF and brain specific angiogenesis inhibitor-1 in glioblastoma: prognostic significance. Oncol Rep 2004, 11(7):863-869.

19. Dickson PV, Hamner JB, Sims TL, Fraga CH, Ng CY, Rajasekeran S, Hagedorn NL, McCarville MB, Stewart CF, Davidoff AM: Bevacizumabinduced transient remodeling of the vasculature in neuroblastoma xenografts results in improved delivery and efficacy of systemically administered chemotherapy. Clin Cancer Res 2007, 13(13):3942-3950.

20. Bao S, Wu Q, Sathornsumetee S, Hao Y, Li Z, Hjelmeland AB, Shi Q, McLendon RE, Bigner DD, Rich JN: Stem cell-like glioma cells promote tumor angiogenesis through vascular endothelial growth factor. Cancer Res 2006, 66(16):7843-7848.

21. Hu B, Guo P, Bar-Joseph I, Imanishi Y, Jarzynka MJ, Bogler O, Mikkelsen T, Hirose T, Nishikawa R, Cheng SY: Neuropilin-1 promotes human glioma progression through potentiating the activity of the HGF/SF autocrine pathway. Oncogene 2007, 26(38):5577-5586.

22. Noguera-Troise I, Daly C, Papadopoulos NJ, Coetzee S, Boland P, Gale NW Lin HC, Yancopoulos GD, Thurston G: Blockade of Dll4 inhibits tumour growth by promoting non-productive angiogenesis. Nature 2006, 444(7122):1032-1037. 
23. Holash J, Maisonpierre PC, Compton D, Boland P, Alexander CR, Zagzag D, Yancopoulos GD, Wiegand SJ: Vessel cooption, regression, and growth in tumors mediated by angiopoietins and VEGF. Science 1999, 284(5422):1994-1998.

24. Stark-Vance V: Bevacizumab and CPT-11 in the treatment of relapsed malignant glioma [abstract]. Neuro Oncol 2005, 7(3):369.

25. Hurwitz $H$, Fehrenbacher L, Novotny W, Cartwright T, Hainsworth J, Heim W, Berlin J, Baron A, Griffing S, Holmgren E, Ferrara N, Fyfe G, Rogers B, Ross R, Kabbinavar F: Bevacizumab plus irinotecan, fluorouracil, and leucovorin for metastatic colorectal cancer. N Engl J Med 2004, 350(23):2335-2342

26. Fine HA, Figg WD, Jaeckle K, Wen PY, Kyritsis AP, Loeffler JS, Levin VA, Black PM, Kaplan R, Pluda JM, Yung WK: Phase II trial of the antiangiogenic agent thalidomide in patients with recurrent high-grade gliomas. J Clin Oncol 2000, 18(4):708-715.

27. Jain RK: Normalizing tumor vasculature with anti-angiogenic therapy: a new paradigm for combination therapy. Nat Med 2001, 7(9):987-989.

28. Vredenburgh JJ, Desjardins A, Herndon JE II, Dowell JM, Reardon DA, Quinn JA, Rich JN, Sathornsumetee S, Gururangan S, Wagner M, Bigner DD, Friedman $\mathrm{AH}$, Friedman HS: Phase II trial of bevacizumab and irinotecan in recurrent malignant glioma. Clin Cancer Res 2007, 13(4):1253-1259.

29. Vredenburgh JJ, Desjardins A, Herndon JE II, Marcello J, Reardon DA, Quinn JA, Rich JN, Sathornsumetee S, Gururangan S, Sampson J, Wagner M, Bailey L, Bigner DD, Friedman AH, Friedman HS: Bevacizumab plus irinotecan in recurrent glioblastoma multiforme. J Clin Oncol 2007, 25(30):4722-4729.

30. Desjardins A, Vredenburgh JJ, Reardon DA, Herndon JE, Marcello J, Peters K, Gururangan S, Sathornsumetee S, Rich JN, Friedman HS: Long-term survival from the initial trial of bevacizumab and irinotecan [abstract]. J Clin Oncol 2010, 28(15 suppl):191s.

31. Friedman HS, Prados M, Wen PY, Mikkelsen T, Schiff D, Abrey LE, Yung WK, Paleologos N, Nicholas MK, Jensen R, Vredenburgh J, Huang J, Zheng M, Cloughesy T: Bevacizumab alone and in combination with irinotecan in recurrent glioblastoma. J Clin Oncol 2009, 27(28):4733-4740.

32. Cloughesy T, Vredenburgh JJ, Day B, Das A, Friedman HS, the BRAIN Investigators: Updated safety and survival of patients with relapsed glioblastoma treated with bevacizumab in the BRAIN stud [abstract]. J Clin Oncol 2010, 28(15 suppl):181s.

33. Narayana A, Kelly P, Golfinos J, Parker E, Johnson G, Knopp E, Zagzag D, Fischer I, Raza S, Medabalmi P, Eagan P, Gruber ML: Antiangiogenic therapy using bevacizumab in recurrent high-grade glioma: impact on local control and patient survival. J Neurosurg 2009, 110(1):173-180.

34. Poulsen HS, Grunnet K, Sorensen M, Olsen P, Hasselbalch B, Nelausen K, Kosteljanetz $M$, Lassen $U$ : Bevacizumab plus irinotecan in the treatment patients with progressive recurrent malignant brain tumours. Acta Oncol 2009, 48(1):52-58.

35. Zuniga RM, Torcuator R, Jain R, Anderson J, Doyle T, Ellika S, Schultz L, Mikkelsen T: Efficacy, safety and patterns of response and recurrence in patients with recurrent high-grade gliomas treated with bevacizumab plus irinotecan. J Neurooncol 2009, 91(3):329-336.

36. Norden AD, Young GS, Setayesh K, Muzikansky A, Klufas R, Ross GL, Ciampa AS, Ebbeling LG, Levy B, Drappatz J, Kesari S, Wen PY: Bevacizumab for recurrent malignant gliomas: efficacy, toxicity, and patterns of recurrence. Neurology 2008, 70(10):779-787.

37. Verhoeff JJ, Lavini C, van Linde ME, Stalpers $L$, Majoie CB, Reijneveld JC, van Furth WR, Richel DJ: Bevacizumab and dose-intense temozolomide in recurrent high-grade glioma. Ann Oncol 2010, 21(8):1723-1727.

38. Reardon DA, Desjardins A, Vredenburgh JJ, Gururangan S, Sampson JH, Sathornsumetee S, McLendon RE, Herndon JE II, Marcello JE, Norfleet J, Friedman AH, Bigner DD, Friedman HS: Metronomic chemotherapy with daily, oral etoposide plus bevacizumab for recurrent malignant glioma: a phase II study. Br J Cancer 2009, 101(12):1986-1994.

39. Thompson EM, Dosa E, Kraemer DF, Neuwelt EA: Bevacizumab plus carboplatin increases survival in patients with recurrent malignant glioma [abstract]. Neuro Oncol 2009, 11(5):625-626.

40. Yang JC, Haworth L, Sherry RM, Hwu P, Schwartzentruber DJ, Topalian SL, Steinberg SM, Chen HX, Rosenberg SA: A randomized trial of bevacizumab, an anti-vascular endothelial growth factor antibody, for metastatic renal cancer. N Engl J Med 2003, 349(5):427-434.
41. Semrad TJ, O'Donnell R, Wun T, Chew H, Harvey D, Zhou H, White RH: Epidemiology of venous thromboembolism in 9489 patients with malignant glioma. J Neurosurg 2007, 106(4):601-608.

42. Puduvalli VK, Giglio P, Groves MD, Hess KR, Gilbert MR, Mahankali S, Jackson EF, Levin VA, Conrad CA, Hsu SH, Colman H, de Groot JF, Ritterhouse MG, Ictech SE, Yung WK: Phase II trial of irinotecan and thalidomide in adults with recurrent glioblastoma multiforme. Neuro Oncol 2008, 10(2):216-222.

43. Fadul CE, Kingman LS, Meyer LP, Cole BF, Eskey CJ, Rhodes $\mathrm{CH}$, Roberts DW Newton HB, Pipas JM: A phase II study of thalidomide and irinotecan for treatment of glioblastoma multiforme. J Neurooncol 2008, 90(2):229-235.

44. Groves MD, Puduvalli VK, Chang SM, Conrad CA, Gilbert MR, TremontLukats IW, Liu TJ, Peterson P, Schiff D, Cloughesy TF, Wen PY, Greenberg H, Abrey LE, DeAngelis LM, Hess KR, Lamborn KR, Prados MD, Yung WK: A North American brain tumor consortium (NABTC 99-04) phase II trial of temozolomide plus thalidomide for recurrent glioblastoma multiforme. J Neurooncol 2007, 81(3):271-277.

45. Fine HA, Wen PY, Maher EA, Viscosi E, Batchelor T, Lakhani N, Figg WD, Purow BW, Borkowf CB: Phase II trial of thalidomide and carmustine for patients with recurrent high-grade gliomas. J Clin Oncol 2003, 21(12):2299-2304.

46. Reardon D, Friedman H, Yung WKA, Brada M, Conrad C, Provenzale J, Jackson E, Serajuddin H, Chen B, Laurent D: A phase I/II trial of PTK787/ZK 222584 (PTK/ZK), a novel, oral angiogenesis inhibitor, in combination with either temozolomide or lomustine for patients with recurrent glioblastoma multiforme (GBM) [abstract]. Proc Am Soc Clin Oncol 2004, 22(14s):110s.

47. Motzer RJ, Hutson TE, Tomczak P, Michaelson MD, Bukowski RM, Rixe O, Oudard S, Negrier S, Szczylik C, Kim ST, Chen I, Bycott PW, Baum CM, Figlin RA: Sunitinib versus interferon alfa in metastatic renal-cell carcinoma. N Engl J Med 2007, 356(2):115-124.

48. Burger RA, Sill MW, Monk BJ, Greer BE, Sorosky Jl: Phase II trial of bevacizumab in persistent or recurrent epithelial ovarian cancer or primary peritoneal cancer: a Gynecologic Oncology Group Study. J Clin Oncol 2007, 25(33):5165-5171.

49. Kreisl TN, Kim L, Moore K, Duic P, Royce C, Stroud I, Garren N, Mackey M, Butman JA, Camphausen K, Park J, Albert PS, Fine HA: Phase II trial of single-agent bevacizumab followed by bevacizumab plus irinotecan at tumor progression in recurrent glioblastoma. J Clin Oncol 2009, 27(5):740-745.

50. Reardon DA, Fink KL, Mikkelsen T, Cloughesy TF, O'Neill A, Plotkin S, Glantz M, Ravin P, Raizer JJ, Rich KM, Schiff D, Shapiro WR, BurdetteRadoux S, Dropcho EJ, Wittemer SM, Nippgen J, Picard M, Nabors LB: Randomized phase II study of cilengitide, an integrin-targeting arginineglycine-aspartic acid peptide, in recurrent glioblastoma multiforme. J Clin Oncol 2008, 26(34):5610-5617.

51. Fink K, Mikkelsen T, Nabors LB, Ravin P, Plotkin SR, Schiff D, Hicking C, Picard $M$, Reardon DA: Long-term effects of cilengitide, a novel integrin inhibitor, in recurrent glioblastoma: A randomized phase lla study [abstract]. J Clin Oncol 2010, 28(15 suppl):182s.

52. Wachsberger PR, Burd R, Cardi C, Thakur M, Daskalakis C, Holash J, Yancopoulos GD, Dicker AP: VEGF trap in combination with radiotherapy improves tumor control in u87 glioblastoma. Int J Radiat Oncol Biol Phys 2007, 67(5):1526-1537.

53. De Groot JF, Wen PY, Lamborn K, Chang S, Cloughesy TF, Chen AP, DeAngelis LM, Mehta MP, Gilbert MR, Yung WK, Prados MD: Phase II single arm trial of aflibercept in patients with recurrent temozolomideresistant glioblastoma: NABTC 0601 [abstract]. J Clin Oncol 2008, 26(15 suppl):94s.

54. Wen PY, Prados M, Schiff D, Reardon DA, Cloughesy T, Mikkelsen T, Batchelor T, Drappatz J, Chamberlain MC, De Groot JF: Phase II study of XL184 (BMS 907351), an inhibitor of MET, VEGFR2, and RET, in patients (pts) with progressive glioblastoma (GB) [abstract]. J Clin Oncol 2010, 28(15 suppl):181s.

55. Khasraw M, Abrey LE, Lassman AB, Hormigo A, Nolan C, Gavrilovic IT, Mellinghoff IK, Reiner AS, DeAngelis LM, AM Omuro AM: Phase II trial of continuous low-dose temozolomide (TMZ) for recurrent malignant glioma (MG) with and without prior exposure to bevacizumab (BEV) [abstract]. J Clin Oncol 2010, 28(15 suppl):196s.

56. Quant EC, Norden AD, Drappatz J, Muzikansky A, Doherty L, Lafrankie D, Ciampa A, Kesari S, Wen PY: Role of a second chemotherapy in recurrent 
malignant glioma patients who progress on bevacizumab. Neuro Oncol 2009, 11(5):550-555.

57. Scott BJ, Quant EC, McNamara MB, Ryg PA, Batchelor TT, Wen PY: Bevacizumab salvage therapy following progression in high-grade glioma patients treated with VEGF receptor tyrosine kinase inhibitors. Neuro Oncol 2010, 12(6):603-607.

58. Iwamoto FM, Abrey LE, Beal K, Gutin PH, Rosenblum MK, Reuter VE, DeAngelis LM, Lassman AB: Patterns of relapse and prognosis after bevacizumab failure in recurrent glioblastoma. Neurology 2009, 73(15):1200-1206.

59. Torcuator RG, Thind R, Anderson J, Doyle T, Haythem A, Ryu S, Jain R, Mohan YS, Schultz L, Rosenblum ML, Mikkelsen T: The role of fractionated stereotactic radiosurgery for malignant gliomas that had progressed on bevacizumab [abstract]. Neuro Oncol 2009, 11(5):664.

60. Gerstner ER, Chen PJ, Wen PY, Jain RK, Batchelor TT, Sorensen G: Infiltrative patterns of glioblastoma spread detected via diffusion MRI after treatment with cediranib. Neuro Oncol 2010, 12(5):466-472.

61. de Groot JF, Fuller G, Kumar AJ, Piao Y, Eterovic K, Ji Y, Conrad CA: Tumor invasion after treatment of glioblastoma with bevacizumab: radiographic and pathologic correlation in humans and mice. Neuro Oncol 2010, 12(3):233-242.

62. Gruber ML, Kunnakkat S, Medabalmi P, Gruber DB, Golfinos J, Parker E, Narayana A: Change in pattern of relapse in newly diagnosed high-grade glioma following bevacizumab therapy [abstract]. J Clin Oncol 2010, 28(15 suppl):184s.

63. Platten M, Dörner N, Hofer S, Schäfer N, Schemmer D, Weller M, Bendszus M, Wick W, Wick A: Evaluation of distant spread in bevacizumab-treated versus control-treated patients with malignant gliomas: a matched-pair study [abstract]. J Clin Oncol 2010, 28(15 suppl):195s.

64. Pope WB, Xia Q, Das A, Hambleton J, Kim H, Brown M, Goldin J, Cloughesy TF: Patterns of progression in patients with glioblastoma at first or second relapse treated with bevacizumab alone or in combination with irinotecan in the BRAIN study [abstract]. Neuro Oncol 2009, 11(5):626.

65. Chamberlain M: Radiographic patterns of relapse in glioblastoma [abstract]. J Clin Oncol 2010, 28(15 suppl):185s.

66. Shapiro LQ, Karimi S, Gutin PH, Iwamoto FM, Zhang Z, Lassman AB, Abrey LE, Beal K: Patterns of failure following concurrent bevacizumab and hypofractionated stereotactic radiotherapy for recurrent high-grade glioma [abstract]. Int J Radiat Oncol Biol Phys 2009, 75(3 suppl):s125.

67. Chamberlain MC: Radiographic patterns of relapse in glioblastoma. J Neurooncol 2011, 101(2):319-323.

68. Shor AC, Keschman EA, Lee FY, Muro-Cacho C, Letson GD, Trent JC, Pledger WJ, Jove R: Dasatinib inhibits migration and invasion in diverse human sarcoma cell lines and induces apoptosis in bone sarcoma cells dependent on SRC kinase for survival. Cancer Res 2007, 67(6):2800-2808.

69. Lee C-G, Heijn M, di Tomaso E, Griffon-Etienne G, Ancukiewicz M, Koike C, Park KR, Ferrara N, Jain RK, Suit HD, Boucher Y: Anti-vascular endothelial growth factor treatment augments tumor radiation response under normoxic or hypoxic conditions. Cancer Res 2000, 60(19):5565-5570.

70. Gorski DH, Beckett MA, Jaskowiak NT, Calvin DP, Mauceri HJ, Salloum RM, Seetharam S, Koons A, Hari DM, Kufe DW, Weichselbaum RR: Blockage of the vascular endothelial growth factor stress response increases the antitumor effects of ionizing radiation. Cancer Res 1999, 59(14):3374-3378.

71. Kermani $P$, Leclerc $G$, Martel $R$, Fareh J: Effect of ionizing radiation on thymidine uptake, differentiation, and VEGFR2 receptor expression in endothelial cells: the role of VEGF(165). Int J Radiat Oncol Biol Phys 2001, 50(1):213-220

72. Magnon C, Opolon P, Ricard M, Connault E, Ardouin P, Galaup A, Métivier D, Bidart JM, Germain S, Perricaudet M, Schlumberger M: Radiation and inhibition of angiogenesis by canstatin synergize to induce HIF1alpha-mediated tumor apoptotic switch. J Clin Invest 2007, 117(7):1844-1855.

73. Winkler F, Kozin SV, Tong RT, Chae SS, Booth MF, Garkavtsev I, Xu L, Hicklin DJ, Fukumura D, di Tomaso E, Munn LL, Jain RK: Kinetics of vascular normalization by VEGFR2 blockade governs brain tumor response to radiation: role of oxygenation, angiopoietin-1, and matrix metalloproteinases. Cancer Cell 2004, 6(6):553-563.
74. Ma BB, Bristow RG, Kim J, Siu LL: Combined-modality treatment of solid tumors using radiotherapy and molecular targeted agents. J Clin Oncol 2003, 21(14):2760-2776.

75. Bao S, Wu Q, McLendon RE, Hao Y, Shi Q, Hjelmeland AB, Dewhirst MW, Bigner DD, Rich JN: Glioma stem cells promote radioresistance by preferential activation of the DNA damage response. Nature 2006, 444(7120):756-760.

76. Willett CG, Boucher Y, Duda DG, di Tomaso E, Munn LL, Tong RT, Kozin SV, Petit L, Jain RK, Chung DC, Sahani DV, Kalva SP, Cohen KS, Scadden DT, Fischman AJ, Clark JW, Ryan DP, Zhu AX, Blaszkowsky LS, Shellito PC, MinoKenudson M, Lauwers GY: Surrogate markers for antiangiogenic therapy and dose-limiting toxicities for bevacizumab with radiation and chemotherapy: continued experience of a phase I trial in rectal cancer patients. J Clin Oncol 2005, 23(31):8136-8139.

77. Czito BG, Bendell JC, Willett CG, Morse MA, Blobe GC, Tyler DS, Thomas J, Ludwig KA, Mantyh CR, Ashton J, Yu D, Hurwitz HI: Bevacizumab, oxaliplatin, and capecitabine with radiation therapy in rectal cancer: phase I trial results. Int I Radiat Oncol Biol Phys 2007, 68(2):472-478.

78. Lai A, Filka E, McGibbon B, Nghiemphu PL, Graham C, Yong WH, Mischel P, Liau LM, Bergsneider M, Pope W, Selch M, Cloughesy T: Phase II pilot study of bevacizumab in combination with temozolomide and regional radiation therapy for up-front treatment of patients with newly diagnosed glioblastoma multiforme: interim analysis of safety and tolerability. Int J Radiat Oncol Biol Phys 2008, 71(5):1372-1380.

79. Narayana A, Golfinos JG, Fischer I, Raza S, Kelly P, Parker E, Knopp EA, Medabalmi P, Zagzag D, Eagan P, Gruber ML: Feasibility of using bevacizumab with radiation therapy and temozolomide in newly diagnosed high-grade glioma. Int J Radiat Oncol Biol Phys 2008, 72(2):383-389.

80. Lai A, Nghiemphu P, Green RM, Spier L, Peak S, Phuphanich S, Fehrenbacher L, Kolevska T, Polikoff JA, Cloughesy TF: Updated results of phase II trial of bevacizumab in combination with temozolomide and regional radiation therapy for upfront treatment of patients with newly diagnosed glioblastoma multiforme [abstract]. Neuro Oncol 2009, 11(5):632.

81. Nicholas MK, Lucas RV, Arzbaecher J, Paleologos N, Krouwer H, Malkin M, Omar A, Vick NA: Bevacizumab in combination with temozolomide in the adjuvant treatment of newly diagnosed glioblastoma multiforme: Preliminary results of a phase II study [abstract]. J Clin Oncol 2009, 27(15 suppl):91s.

82. Vredenburgh JJ, Desjardins A, Reardon DA, Peters K, Kirkpatrick J, Herndon JE, Marcello J, Bailey L, Threatt S, Friedman HS: Bevacizumab (BEV) in combination with temozolomide (TMZ) and radiation therapy (XRT) followed by BEV, TMZ, and irinotecan for newly diagnosed glioblastoma multiforme (GBM) [abstract]. J Clin Oncol 2010, 28(15 suppl):185s.

83. Omuro AM, Beal K, Karimi S, Chan TA, Panageas K, Nayak L, Seko B, DeAngelis LM, Abrey LE, Gutin PH: Phase II study of bevacizumab (BEV), temozolomide (TMZ), and hypofractionated stereotactic radiotherapy (HFSRT) for newly diagnosed glioblastoma (GBM) [abstract]. J Clin Oncol 2010, 28(15 suppl):188s.

84. Shih KC, Spigel DR, Burris III HA, Brown RH, Shepard GC, Hainsworth JD: Phase II trial of radiation therapy/temozolomide/bevacizumab followed by bevacizumab/everolimus in the first-line treatment of glioblastoma multiforme (GBM) [abstract]. J Clin Oncol 2010, 28(15 suppl):198s.

85. Hofland KF, Poulsen HS, Sørensen MP, Ask A, Bertelsen AK, Spahn-Horn S, Hansen S, Schulz HP, Lassen U: First-line therapy with bevacizumab and irinotecan versus bevacizumab and temozolomide and delayed concomitant radiotherapy in newly diagnosed primary glioblastoma multiforme: early results from a randomized phase II study [abstract]. Neuro Oncol 2009, 11(5):620.

86. van Linde ME, Verhoeff JJC, Stalpers LJA, Reijneveld JC, Richel DJ, Van Furth WR: Feasibility of combined treatment with bevacizumab, radiotherapy, and temozolomide in resectable and unresectable newly diagnosed glioblastoma multiforme [abstract]. Neuro Oncol 2009, 11(5):628.

87. Chinot O, de La Motte T, Zeaiter A, Moore N, Das A, Swamy R, Cloughesy TF: Preclinical and clinical rationale for a phase III trial of bevacizumab combined with the current standard of care in patients with newly diagnosed glioblastoma multiforme (ND-GBM) [abstract]. Neuro Oncol 2009, 11(5):628. 
88. Stupp R, Hegi ME, Neyns B, Goldbrunner R, Schlegel U, Clement PM Grabenbauer GG, Ochsenbein AF, Simon M, Dietrich PY, Pietsch T, Hicking C, Tonn JC, Diserens AC, Pica A, Hermisson M, Krueger S, Picard M, Weller M: Phase I/lla trial of cilengitide and temozolomide with concomitant radiotherapy, followed by cilengitide and temozolomide maintenance therapy in patients with newly diagnosed glioblastoma. $J$ Clin Oncol 2010, 28(16):2712-2718.

89. Brandes AA, Stupp R, Hau P, Lacombe D, Gorlia T, Tosoni A, Mirimanoff RO, Kros JM, van den Bent MJ: EORTC study 26041-22041: phase I/II study on concomitant and adjuvant temozolomide (TMZ) and radiotherapy (RT) with PTK787/ZK222584 (PTK/ZK) in newly diagnosed glioblastoma. Eur J Cancer 2010, 46(2):348-354.

90. Drappatz J, Norden AD, Wong ET, Doherty LM, Lafrankie DC, Ciampa A, Kesari S, Sceppa C, Gerard M, Phan P, Schiff D, Batchelor TT, Ligon KL, Young G, Muzikansky A, Weiss SE, Wen PY: Phase I study of vandetanib with radiotherapy and temozolomide for newly diagnosed glioblastoma. Int J Radiat Oncol Biol Phys 2010, 78(1):85-90.

91. Nabors LB, Fiveash JB, Markert JM, Kekan MS, Gillespie GY, Huang Z, Johnson MJ, Meleth S, Kuo H, Gladson CL, Fathallah-Shaykh HM: A phase 1 trial of ABT-510 concurrent with standard chemoradiation for patients with newly diagnosed glioblastoma. Arch Neurol 2010, 67(3):313-319.

92. Gutin PH, Iwamoto FM, Beal K, Mohile NA, Karimi S, Hou BL, Lymberis S, Yamada Y, Chang J, Abrey LE: Safety and efficacy of bevacizumab with hypofractionated stereotactic irradiation for recurrent malignant gliomas. Int J Radiat Oncol Biol Phys 2009, 75(1):156-163.

93. Niyazi M, Ganswindt U, Schwarz SB, Kreth FW, Tonn JC, Geisler J, la Fougère C, Ertl L, Linn J, Siefert A, Belka C: Irradiation and bevacizumab in high-grade glioma retreatment settings. Int I Radiat Oncol Biol Phys 2010.

94. Batchelor TT, Sorensen AG, di Tomaso E, Zhang WT, Duda DG, Cohen KS, Kozak KR, Cahill DP, Chen PJ, Zhu M, Ancukiewicz M, Mrugala MM, Plotkin S, Drappatz J, Louis DN, Ivy P, Scadden DT, Benner T, Loeffler JS, Wen PY, Jain RK: AZD2171, a pan-VEGF receptor tyrosine kinase inhibitor, normalizes tumor vasculature and alleviates edema in glioblastoma patients. Cancer Cell 2007, 11(1):83-95.

95. Gonzalez J, Kumar AJ, Conrad CA, Levin VA: Effect of bevacizumab on radiation necrosis of the brain. Int J Radiat Oncol Biol Phys 2007, 67(2):323-326.

96. Levin VA, Bidaut L, Hou P, Kumar AJ, Wefel JS, Bekele BN, Prabhu S, Loghin M, Gilbert MR, Jackson EF: Randomized double-blind placebocontrolled trial of bevacizumab therapy for radiation necrosis of the central nervous system. Int J Radiat Oncol Biol Phys 2010.

97. Torcuator R, Zuniga R, Mohan YS, Rock J, Doyle T, Anderson J, Gutierrez J, Ryu S, Jain R, Rosenblum M, Mikkelsen T: Initial experience with bevacizumab treatment for biopsy confirmed cerebral radiation necrosis. J Neurooncol 2009, 94(1):63-68.

98. Desjardins A, Reardon DA, Herndon JE II, Marcello J, Quinn JA, Rich JN, Sathornsumetee S, Gururangan S, Sampson J, Bailey L, Bigner DD, Friedman AH, Friedman HS, Vredenburgh JJ: Bevacizumab plus irinotecan in recurrent WHO grade 3 malignant gliomas. Clin Cancer Res 2008, 14(21):7068-7073.

99. Kreisl TN, Butman JA, Hammoud D, Iwamoto FM, Kim L, Duic P, Albert P, Fine HA: Phase II trial of single-agent bevacizumab followed by bevacizumab plus irinotecan at tumor progression in recurrent anaplastic glioma [abstract]. Neuro Oncol 2009, 11(5):620.

100. Chamberlain MC, Johnston S: Bevacizumab for recurrent alkylatorrefractory anaplastic oligodendroglioma. Cancer 2009, 115(8):1734-1743.

101. Chamberlain MC, Johnston S: Salvage chemotherapy with bevacizumab for recurrent alkylator-refractory anaplastic astrocytoma. J Neurooncol 2009, 91(3):359-367.

102. Gerstner ER, Chen Q, Batchelor T, Sorensen AG: Use of FLAIR MRI in determining glioblastoma response to cediranib [abstract]. J Clin Oncol 2010, 28(15 suppl):195s.

103. Chamberlain MC: Bevacizumab for recurrent malignant gliomas: efficacy, toxicity, and patterns of recurrence. Neurology 2009, 72(8):772-773, author reply $773-774$

104. Verhoeff JJ, van Tellingen $O$, Claes A, Stalpers $L$, van Linde ME, Richel DJ, Leenders WP, van Furth WR: Concerns about anti-angiogenic treatment in patients with glioblastoma multiforme. BMC Cancer 2009, 9:444.

105. Wen PY, Macdonald DR, Reardon DA, Cloughesy TF, Sorensen AG, Galanis E, Degroot J, Wick W, Gilbert MR, Lassman AB, Tsien C, Mikkelsen T, Wong ET,
Chamberlain MC, Stupp R, Lamborn KR, Vogelbaum MA, van den Bent MJ, Chang SM: Updated response assessment criteria for high-grade gliomas: response assessment in Neuro-Oncology Working Group. $J$ Clin Oncol 2010, 28(11):1963-1972.

106. Gerstner ER, Frosch MP, Batchelor TT: Diffusion magnetic resonance imaging detects pathologically confirmed, nonenhancing tumor progression in a patient with recurrent glioblastoma receiving bevacizumab. J Clin Oncol 2010, 28(6):e91-e93.

107. Ferl GZ, Xu L, Friesenhahn M, Bernstein L, Barboriak DP, Port RE: An automated method for nonparametric kinetic analysis of clinical DCEMRI data: application to glioblastoma treated with bevacizumab. Magn Reson Med 2010, 63(5):1366-1375.

108. Sawlani RN, Raizer J, Horowitz SW, Shin W, Grimm SA, Chandler JP, Levy R, Getch C, Carroll TJ: Glioblastoma: a method for predicting response to antiangiogenic chemotherapy by using MR perfusion imaging-pilot study. Radiology 2010, 255(2):622-628.

109. Pope WB, Kim HJ, Huo J, Alger J, Alger J, Brown MS, Gjertson D, Sai V, Young JR, Tekchandani L, Cloughesy T, Mischel PS, Lai A, Nghiemphu P, Rahmanuddin S, Goldin J: Recurrent glioblastoma multiforme: ADC histogram analysis predicts response to bevacizumab treatment. Radiology 2009, 252(1):182-189.

110. Sathornsumetee S, Desjardins A, Vredenburgh JJ, McLendon RE, Marcello J, Herndon JE, Norfleet J, Gururangan S, Friedman HS, Reardon DA: Phase II trial of bevacizumab plus erlotinib for patients with recurrent malignant gliomas: final results [abstract]. J Clin Oncol 2010, 28(15 suppl):193s.

111. Hasselbalch B, Lassen U, Hansen S, Holmberg M, Sørensen M, Kosteljanetz M, Broholm H, Stockhausen MT, Poulsen HS: : Cetuximab, bevacizumab, and irinotecan for patients with primary glioblastoma and progression after radiation therapy and temozolomide: a phase II trial. Neuro Oncol 2010, 12(5):508-516.

112. Batchelor TT, Duda DG, di Tomaso E, Ancukiewicz M, Plotkin SR, Gerstner E, Eichler AF, Drappatz J, Hochberg FH, Benner T, Louis DN, Cohen KS, Chea H, Exarhopoulos A, Loeffler JS, Moses MA, Ivy P, Sorensen AG, Wen PY, Jain RK: Phase II study of cediranib, an oral pan-vascular endothelial growth factor receptor tyrosine kinase inhibitor, in patients with recurrent glioblastoma. J Clin Oncol 2010, 28(17):2817-2823.

113. Schiff D, Reardon DA, Kesari S, Mikkelsen T, De Groot JF, Fichtel L, Coyle TE, Wong E, Eaton C, Silver B: Phase II study of CT-322, a targeted biologic inhibitor of VEGFR-2 based on a domain of human fibronectin, in recurrent glioblastoma (rGBM) [abstract]. J Clin Oncol 2010, 28(15 suppl):182s.

114. US National Institutes of Health Clinicaltrials.gov Web site. [http://www. clinicaltrials.gov].

\section{doi:10.1186/1748-717X-6-2}

Cite this article as: Beal et al:: Antiangiogenic agents in the treatment of recurrent or newly diagnosed glioblastoma: Analysis of single-agent and combined modality approaches. Radiation Oncology 2011 6:2.

\section{Submit your next manuscript to BioMed Central and take full advantage of:}

- Convenient online submission

- Thorough peer review

- No space constraints or color figure charges

- Immediate publication on acceptance

- Inclusion in PubMed, CAS, Scopus and Google Scholar

- Research which is freely available for redistribution

Submit your manuscript at www.biomedcentral.com/submit
C Biomed Central 